\title{
Deconstructing the Constructive Trust
}

\section{LEONARD I. ROTMAN}

With the Supreme Court of Canada's judgment in Soulos $v$. Korkontzilas, the constructive irust has again become the subject of contention in Canadian law. Over the years, jurists and scholars have generated significant debate over the nature and function of the constructive trust and where it ought to be used. While constructive trusss have been implemented in a variety of situations, there has not always been agreement over whether all such uses are appropriate. This debate continued in the Supreme Court of Canada's decision in Soulos. While the majority decision in Soulos has clarified the availability of the constructive trust in Canadian law. the open-endedness of the majority judgmen and the vociferous dissent suggest that the issue may not yet be put to rest. In this article, the author critically examines the Soulos judgment and its potential effects on the law of constructive trusts in Canada.

\begin{abstract}
Depuis larrèt Soulos c. Korkontzilas rendu par la Cour supreme du Canada, la fiducie par interprétation est redevenise un sujet comboversé en droit cantudien. An fil dil remps, les juristes onf engage d'importants debats sur la nature et la fonction de la fiducie d'inferprétation el l'usage qu' il convient den faire. Bien que les fiducies par interprétation soient invoquees dans diverses circonsfances, leur bien-fondé ne fait pas l'unanimité. La Cour suprëme du Canada a poursuivi ce débat dans larrêt Soulos. Quoique la décision majoritaire ail élucide ce recours possible. le caractire otvert de la décision majoritaire et la velhémence du juge dissiden suggèrent que la question est loin d'äre réglée une fois pour toutes. Dans ke present article. I'auteur examine larrit Soulos et les conséquences possibles de la fiducio par interpritation au Canada.
\end{abstract}

\section{TABLE OF CONTENTS}

I. INTRODUCTION ...................... 133

II. RATIONAI.ES FOR THE EXISTENCE OF THE Constructive Trust .................. 134

III. TIIE AVAll.ABIIITY OF CONSTRUCTIVE TRUSTS IN CANADIAN

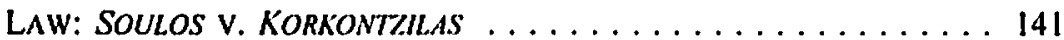

IV. THE IMPLICATIONS OF SOULOS $\ldots \ldots \ldots \ldots \ldots \ldots \ldots \ldots 153$

V. THE EFFECT OF THE CONSTRUCTIVE TRUST ON THIRD PARTIES $\ldots \ldots \ldots \ldots \ldots \ldots \ldots \ldots \ldots \ldots \ldots$

VI. Conclusion $\ldots \ldots \ldots \ldots \ldots \ldots \ldots \ldots \ldots \ldots \ldots \ldots \ldots$

\section{INTRODUC:TION}

A constructive trust is the formula through which the conscience of equity linds expression.'

The constructive trust has enjoyed a lengthy existence, dating back to the seventeenth century. ${ }^{2}$ Since that time it has been the subject of a significant amount of controversy in judicial and academic fora. Debate over the nature of the constructive trust and when

Assistant Prolessor, Faculty of Law, University of Windsor. The author would like to thank Tom Asquith and Tammy Dwosh for their research assistance and the Foundation for L.cgal Research. which provided a grant towards the development and preparation of this article.

Beatly v. Guggenheim Exploration Co., 122 N.E. 378 at 380 (N.Y.C.A., 1919), Cardozo J.

See, for example, Hoht v. Holl (1670), 1 Ch. Cas. 190; 22 E.R. 756. 
it ought to be applied has been plentiful. As Maudsley has noted, "[t]here are few areas of law which are as fertile and as vague as that of Constructive Trusts."

The Supreme Court of Canada's recent decision in Soulos v. Korkontzilas ${ }^{4}$ has provided a reason to reconsider arguments about the nature and function of constructive trusts. Traditionally, in English law, the constructive trust was regarded as a type of trust, standing alongside express trusts, implied trusts, and resulting trusts. It was seen, therefore, as substantive or institutional in nature. This understanding was adopted by other common law jurisdictions, such as Australia and Canada. In 1980, the Canadian law of constructive trusts became enlarged through the development, in Pettkus v. Becker, ${ }^{5}$ of the constructive trust as a remedy for unjust enrichment. The Pettkus decision was subsequently affirmed in a number of cases. ${ }^{6}$ In Soulos, the judgments of McLachlin and Sopinka JJ. considered both pre- and post-Pettkus jurisprudence in their examinations of the contemporary function of constructive trusts in Canadian law.

This article will look to various rationales underlying the imposition of constructive trusts and determine whether the analysis provided by the majority and minority judgments in Soulos is compatible therewith. It will also endeavour to ascertain some of the implications of Soulos in Canadian law. In particular, it will look to the ramifications of having a flexible, open-ended definition of constructive trusts versus one that is limited by the boundaries of a formulaic equation. ${ }^{7}$ Finally, the article will consider an often-neglected issue surrounding the implementation of constructive trusts - the implications of imposing constructive trusts on third parties, such as creditors of constructive trustees.

\section{RAtionales for the Existence of the CONSTRuCtive Trust}

Historically, constructive trusts have been employed in a variety of disparate situations. They have, for example, been used to remedy breaches of fiduciary obligation. ${ }^{8}$ They have also been used to compel strangers to trusts to repair losses caused by their actual breaches of trust, assistance in a breach of trust ${ }^{10}$ or receipt

R.H. Maudsley, "Constructive Trusts" (1977) N.I.L.Q. 123 at 123 [hereinafter Maudsley, "Constructive Trusts"].

(1997), 146 D.L.R. (4th) 214 (S.C.C.) [hereinafter Soulos, SCC].

(1980), 117 D.L.R. (3d) 257 (S.C.C.).

From Sorochan v. Sorochan, [1986] 2 S.C.R. 38 through Peter v. Beblow (1993), 10 I D.L.R. (4th) 621 (S.C.C.).

Such as that developed in Pettkus v. Becker, supra note 5.

See Keech v. Sandford (1726), 25 E.R. 223 (Ch.); Regal (Hastings) Lid. v. Gulliver, [1942] I All E.R. 378 (H.L.) [hereinafter Regal (Hastings)); Canadian Aero Service Lid. v. O'Malley (1973). 40 D.L.R. (3d) 371 (S.C.C.) (hereinafter CanAero]. Phipps v. Boardman, [1967] 2 A.C. 46 (H.L.). The stranger in this situation becomes liable as a trustee de son tort, or a trustee of his or her own wrong; see Black's Law Dictionary, Sth ed. (St. Paul, Minn.: West, 1979) at 403. A person may be found to be a trustee de son tort where that person is a stranger to the trust, voluntarily assumes a trustee's obligations, and commits a breach of trust. The stranger must have possession and control over the trust property that does not result from an agency relationship between the stranger and the actual trustee of the trust. 
of trust property in breach of trust." In addition, constructive trusts have been imposed to enforce gifts in situations where donees have done everything in their power to perfect the gifts, but who have nevertheless failed to do so in law. ${ }^{12}$ There are a variety of other circumstances in which constructive trusts have been implemented. Professor Austin lists the following as situations in which constructive trusts have been applied:

(a) the "constructive trust" imposed on the vendor of land;

(b) the trust of the purchase money held by a mortgagee who has exercised a power of sale;

(c) the trust imposed when property is obtained by fraudulent conduct, such as undue influence;

(d) the trust imposed on the Keech v. Sandford principle;

(e) the trust of a profit improperly made by a fiduciary;

(f) the trusteeship of a person who receives or deals with trust property or knowingly assists a fiduciary in a dishonest and fraudulent design;

(g) the trust arising from a contract to make mutual wills, and possibly also that arising from a fully secret trust;

(h) the trust imposed to prevent an unconscientious assertion of title against a contributor to acquisition or improvement of the property, a person

This will occur in Canadian law where a stranger to the trust knowingly assists in the fraudulent and dishonest breach of trust by a trustec. The degree of knowledge required is actual knowledge, although recklessness or wilful blindness will suffice. See Air Canada v. M \& L. Travel, [1993] 3 S.C.R. 787. Note, however, that in Royal Brunei Airlines Sdn. Bhd. v. Tan Kok Ming, [1995] 2 A.C. 378 (P.C.), the Privy Council held that liability for knowing assistance required the stranger's assistance to be fraudulent and dishonest, whether or not the breach of trust was, itself, fraudulent or dishonest. The Supreme Court of Canada has since affirmed the $M \& L$ Travel formulation of knowing assistance liability in Citadel General Assurance Co. v. Lloyds Bank Canada (1997), 152 D.L.R. (4th) 411 (S.C.C.) [hereinafter Citadel] and Gold v. Rosenberg (1997), 152 D.L.R. (4th) 385 (S.C.C.) [hereinafter Gold].

" To attract liability under knowing receipt, a stranger must receive trust property acquired in breach of trust in the stranger's personal capucity and for the stranger's own use or benefit. 'The degree of knowledge required is constructive - whether a reasonable person ought to have known how the property was acquired or ought to have made appropriate inquiries in situations where such inquiries were warranted. See Ciradel, ibid. and Gold, ibid. For greater discussion of these cases, see L.J. Rotman, "Developments in Trust Law: The $1997-98$ Term" (1998) 10 S.C.L.R. (2d) (forthcoming).

12 See, for example, Re Rose, [1952] Ch. 499, which is an exception to the maxim that "Equity will not assist a volunteer" reflected in cases such as Milroy v. Lord (1862), 4 De G.F. \& J. 264, 45 E.R. 1185 (C.A.). 
with whom the title holder has made an informal agreement or to whom he has granted a license, and certain others. ${ }^{13}$

In addition to this list, there are still other situations in which constructive trusts have been used. Austin notes that Maudsley ${ }^{14}$ has also included persons who take trust property without being able to establish the defence of bona fide purchaser, where legal and equitable estates have been separated, and where property is acquired by killing. ${ }^{\text {is }}$ Austin also suggests adding situations where donors purport to make gifts of property before they acquire it, thereby fostering the donee's reasonable expectation of benefit. ${ }^{16}$ In addition, there is also the notion of the "constructive trust of a new model," proposed by Lord Denning M.R., which is based on the dictates of "justice and good conscience." ${ }^{\text {N17 }}$ Not surprisingly, there is substantial disagreement among commentators as to the categories used or whether some of them are constructive trusts at all. ${ }^{18}$

A significant detriment to the use of these lists is that they are often mistakenly viewed as obviating the need to explain why a particular situation warrants a finding

R.P. Austin, "Constructive Trusts" in P.D. Finn, ed., Essays in Equity (Sydney: Law Book Co., 1985) at 196. Austin suggests at 197 that there is a "heartland" to the constructive trust, which focuses on two areas, fiduciary dutics [categories (d) and (e)] and receipt, dealing, and involvement [category (f)]. Compare this list with that suggested by Maudsley, "Constructive Trusts," supra note 3 at 138:

i. Unauthorized acquisition of property by a fiduciary or by a stranger who acquires notice of the circumstances giving rise to the beneficial owner's claim. The renewal of a least comes into this calegory.

ii. Property acquired by the survivor of makers of mutual wills.

iii. The vendor under a contract for the sale of land.

iv. The mortgagee in possession of purchase money after exercising the mortgagee's power of sale.

v. A beneficiary under a fraudulent conveyance.

vi. Acquisition of property subject to a trust by anyone other than a bona fide purchaser of the legal estate for value without notice.

vii. Where the legal estate is in onc person, and the beneficial interest in another.

viii. Property acquired by killing.

ix. Fully secret trusts.

See R.H. Maudsley \& J.E. Martin, Hanbury and Maudsley, Modern Equity, llth ed. (London: Sweet \& Maxwell, 1981) c. 14. Note also points vi-viii in Maudsley's list, ibid.

Austin, supra note 13 at 197.

Relying upon Le Compte v. Public Trustee, [1983] 2 N.S.W.L.R. 109.

See, for example, Hussey v. Palmer, [1972] I W.L.R. 1286 (C.A.); Eves v. Eves, [1975] 1 W.L.R. 1338 (C.A.). It should be noted that, while the Privy Council rejected the constructive trust based on good conscience in Re Goldcorp Exchange Led. (In Receivership), [1994] 2 All E.R. 806 (P.C.), it was affirmed by the majority judgment in Soulos, SCC, supra note 4.

Is Note, for example, D.W.M. Watcrs, The Consiructive Trust: The Case for a New Approach in English Law (London: Athlone Press, 1964) [hereinafter Waters, The Constructive Trust], in which the author suggests, at 3 , that listing under constructive trusts situations where the unconscionability of a defendant's retention of property is such that that person ought not be able to retain it is "no more concerned with the law of trusts than is a quasi-contract." See the discussion of constructive trusts based on good conscience, below. 
of constructive trust. ${ }^{19}$ They are generally not thematically linked; instead, they are simply a method of classifying or categorizing situations in which constructive trusts have been implemented. Such categorization does little to rationalize when or why a constructive trust ought to be imposed. ${ }^{20}$ According to Waters, such taxonomic endeavours have created a "cul-de-sac of legal reasoning." 21 The use of unexplained lists and categories is not exclusive to the area of constructive trusts, though. ${ }^{22}$

The diverse situations in which constructive trusts have been imposed demonstrate that attempts to provide a comprehensive definition of the constructive trust are likely to result in failure. As Maudsley has stated, "It would be helpful to have a precise definition of a constructive trust. But that is a thankless task. No-one indeed has yet defined a trust." ${ }^{\text {"23 }}$ Whether dealing with constructive trusts or other equitable doctrines, it ought to be recognized that providing compendious definitions is unwise, given that Equity itself is not susceptible to precise definition. ${ }^{24}$ Nevertheless, the lack of definition is not as prohibitive to achieving an understanding of the function of constructive trusts as may appear upon first glance. As Riddall acknowledges, "the fact that no satisfactory definition of a thing has ever been given has never been a bar to the recognition by the law that the thing concerned exists." 25

The law does not always proceed from the definition of a concept through to its application to the facts and the fashioning of a remedy where required. In many circumstances, courts construct an understanding of a concept that is appropriate to the facts in issue and does not pretend to be a general or inclusive definition. ${ }^{26}$ The constructive trust ought to be viewed in this light. Consequently, when dealing with the constructive trust, it is preferable to resign ourselves to the fact that "... the best that

As E.J. Weinrib explained in "The Fiduciary Obligation" (1975) 25 U.T.L.J. 1 at S: "[t]he existence of a list of nominate relations dulls the mind's sensitivity to the purposes for which the list has evolved and tempts the court to regard the list as exhaustive and to refuse admittance to new relations which have been created as a matter of business exigency."

This criticism is evident in the works of other commentators. The premise for G. Elias' work, Explaining Consiructive Trusts (London: Clasendon Press, 1990) is to rationalize the various situations in which constructive trusts have been imposed rather than simply to count off assorted forms. One matter that Elias appears to overlook, though, is the very real possibility that his endeavour may be an attempt to rationalize that which cannot be rationalized. Waters, The Constructive Trust, supra note 18 at 3.

This author has criticized similar practices vis-à-vis fiduciary relationships: see L.I. Rotman, Parallel Paths: Fiduciary Doctrine and the Crown-Native Relationship in Canada (Toronto: University of Toronto Press, 1996) [hereinafter Rotman, Parallel Paths]; Rotman, "Fiduciary Doctrine: A Concept in Need of Understanding" (1996) 34 Alta. L. Rev. 821 [hereinafter Rotman, "Fiduciary Doctrine"]. Maudsley, "Constructive Trusts," supra note 3 at 138. Sec H.G. Hanbury, "The Field of Modern Equity" (1929) 45 L.Q. Rev. 196 at 196. J.G. Riddall, The Law of Trusts, Sth ed. (London: Butterworths, 1996) at 450.

Riddall suggests, ibid., that "Throughout English law, we find that if we ask 'What is $X$ ?' the court will reply 'You tell us the facts and we will tell you whether $X$ exists."' One example of the law proceeding in this manner may be seen in the area of fiduciary law. Although there is no absolute definition of what a fiduciary relationship is, that has not prevented courts from applying fiduciary doctrine and fashioning understandings of fiduciary relations appropriate to the facts in issue. See Rotman, "Fiduciary Doctrine," supra note 22 at 825-30. 
we can do is to give a rough working description of it."27 Perhaps this helps to explain Cardozo J.'s famous, albeit broad, statement that introduced this article.

Notwithstanding the difficulty in attempting to delineate the constructive trust, many have proffered at least partial definitions of what constructive trusts are and when they may be properly used. ${ }^{28}$ Most describe the constructive trust as an institution arising by operation of law. ${ }^{29}$ How does this characterization assist in understanding the constructive trust? It is intended to set the constructive trust apart from the express trust or the resulting trust, which are said to arise by intention of the creator of the trust. ${ }^{30}$ However, it may be seen that some trusts which are said to arise by operation of law are sometimes based in a desire to effectuate intention, ${ }^{31}$ while other trusts deemed to arise by virtue of intent are, in fact, formed by operation of law. ${ }^{32}$

Describing constructive trusts as arising by the operation of law is where the substantial agreement among commentators ends. While some proceed to describe the constructive trust as substantive or institutional, ${ }^{33}$ others maintain that it exists only

A.W. Scott, "Constructive Trusts" (1955) 71 L.Q. Rev. 39 at 39.

21 The majority of these have been included in comprehensive casebooks and textbooks on trust law. See, for example, D.W.M. Waters, Trust Law, 2d ed. (Toronto: Carswell, 1984) c. 11; A.H. Oosterhoff \& E.E. Gillese, Text, Commentary and Cases on Trusts, 4 th ed. (Toronto: Carswell, 1992) c. 8; J.E. Martin, Hanbury and Martin, Modern Equity, 15th ed. (London: Sweet \& Maxwell, 1997) c. 12. See also A.J. Oakley, Constructive Trusts, 2nd ed. (London: Sweet \& Maxwell, 1987); and M. Cope, Constructive Trusts (Sydney: Law Book Co., 1992).

See, for, example, the references, ibid. In Waters, The Constructive Trust, supra note 18, Waters explains that while there is disagreement about the nature and importance of the constructive trust, " $I$ is at least accepted by courts and theorists that this trust is imposed by the law, and that the intention of the parties, who it affects, is consequently irrelevant." For a contrary view, sec Elias, supra note 20 at $152-54$.

The difference in intent is that with the express trust, there is an intent to benefit another person through the creation of the trust, while, with the resulting trust, there is an intent to retain the interest in property whose legal title has passed to another or, altematively, an intent to have the legal title to property that has been transferred to another person revert back to the original owner. This intent, as evidenced in numerous cases, may be actual, inferred, or presumed.

See Re Rose, supra note 12, where a constructive trust was imposed over a gift of shares from a donor to his daughter that was not perfected before his death because of the company's delay in registering the transfer. The court held that since the donor had done everything in his power to perfect the gift, his intention should be given effect, notwithstanding that perfection did not take place.

32 In actuality, all trusts may be seen to arise by operation of law, since only those trusts that are sanctioned by law are given legal foree and effect, regardless of whether the intent to create a trust may be discerned. Although a settlor may wish to create a trust to benefit certain individuals and is able to satisfy the three certainties - intent, subject matter, and object - no trust will be deemed to exist if the law deems it unfit for sanction, such as where the trust would be contrary to public policy. See H.A.J. Ford \& W.A. Lee, Principles of the Law of Trusts, 3d ed. (Sydncy: LBC Information Services, 1996) at 22000.

"Which is derived from the traditional English approach, described, supra, that is represented largely in English and Australian treatises on trusts. See also P. Birks, "Trusts Raised to Reverse Unjust Enrichment: The Wesideutsche Case" (1996] 4 R.L.R. 3 at 13-14. 
as a remedy. ${ }^{34}$ Indeed, there are those who believe that the constructive trust may be both substantive and remedial. ${ }^{35}$

For all of the debate over the substantive versus remedial nature of the constructive trust, there are those who suggest that the issue is largely redundant. In Chase Manhattan Bank v. Israel-British Bank, Goulding J. explained that rights and remedies in law are "indissolubly connected and correlated, each contributing in historical dialogue to the development of the other." 36 To separate the two would be "as idle ... as to ask whether thought is a mental or cerebral process." ${ }^{37}$ Similar sentiments were expressed by Deane J. in Muschinski v. Dodds. "[F]or the student of equity, there can be no true dichotomy between the two notions." In "The Constructive Trust in Evolution," Waters cites both of these judicial comments and adds that "[t]he differences are over terminology and the whole thing is the chasing of rainbows; ..."

The difficulty with the debate over whether the constructive trust is substantive or remedial is that these terms mean different things to different people. Thus, it is not always possible to ascertain precisely what is meant when it is said that a constructive trust is substantive or remedial. For example, when it is said that a constructive trust is substantive, that does not require that it has the same effect in all contexts ${ }^{40}$ or that it cannot have a remedial function - such as to prevent fraud." Similarly, when a constructive trust is said to be remedial, that does not mean that it exists only to remedy unjust enrichment. It may equally provide a remedy by mandating a transfer of property from one person to another because of the former's wrongdoing where no unjust enrichment existed. Moreover, even if a constructive trust is used to remedy unjust enrichment, it may give rise to a more conventional form of trust or it may

This approach gained favour early in American jurisprudence and spread to Canada in the Supreme Court of Canada's judgment in Pettkus v. Becker, supra note 5. Notable proponents of this approach include R. Pound, "The Progress of the Law" (1920) 33 Harv. L. Rev. 420; W.A. Scavey \& A.W. Scott, "Restitution" (1938) 54 L.Q. Rev. 29; Scoth, supra note 27; and Waters, The Constructive Trust, supra note 18.

Nole Muschinski v. Dodds, [1986] 52 A.L.J.R. at 65 (H.C.), Deane J.; R.H. Maudsley, "Proprietary Remedies for the Recovery of Money" (1959) 75 L.Q. Rev. 234 at 237 [hereinafter Maudsley, "Proprietary Remedies"]; and J.L. Dewar, "The Development of the Remedial Constructive Trust" (1982) 60 Can. Bar Rev. 265 at 266. For a consideration of the substantive and remedial views of constructive trusts, see D.W.M. Waters, "The Constructive Trust in Evolution: Substantive and Remedial" (1990-91) 10 Est. \& Tr. J. 334 [hereinafler Waters, "The Constructive Trust in Evolution"]; and A.J. Oakley, "Has the Constructive Trust Become a General Equitable Remedy?" [1973] C.L.R. 17.

Ibid.

Supra note 35 at 65.

Waters, "The Constructive Trust in Evolution," supra note 35 at 334.

See the discussion in note 47, infra and its accompanying text.

Sec, for example, Rochefoucauld v. Boustead, [1897] I Ch. 196 (C.A.); Bannister v. Bannister, [1948] 2 All E.R. 133 (C.A.). See also G.P. Costigan, Jr., "Constructive Trusts Based on Promises Made to Secure Bequests, Devises, or Intestate Succession" (1914-15) 28 Harv. L. Rev. 237 at 366. 
simply transfer title. ${ }^{42}$ Therefore, it could be argued that the polarization of the constructive trust, as "substantive" or "institutional" on one side and "remedial" on the other, may actualiy provide greater confusion while adding little or no substance to constructive trust analysis.

This latter notion was adopted by Deane J. in Muschinski v. Dodds. ${ }^{43}$ He suggested that the constructive trust is both an institution and a remedy and that the dichotomy between the terms has largely been the result of a lack of definition. ${ }^{44}$ He explained that the constructive trust developed as a remedial relationship that was superimposed upon common law rights by the Court of Chancery. However, in its modern context, he held that the constructive trust ought to be regarded as "a remedial institution which equity imposes regardless of actual or presumed agreement or intention (and subsequently protects) to preclude the retention or assertion of beneficial ownership of property to the extent that such retention or assertion would be contrary to equitable principle." 4 As Deane J. later explained, while there may be a "superficial plausibility" in viewing "institutional" and "remedial" as competing characterizations of constructive trusts, such a separation cannot withstand critical analysis. ${ }^{46}$

- Before leaving the substantive/institutional versus remedial debate, a further point of clarification is necessary. Describing the constructive trust as substantive or institutional ought not create the assumption that it has a precise and identical application to each and every fact situation. ${ }^{47}$ The constructive trust, as an equitable device, is discretionary. It is, therefore, dependent on a judicial determination based on the facts and may be adjusted as circumstances require. ${ }^{48}$ For example, the date upon which the constructive trust is deemed to be operative may be adjusted to account for the effects of such a declaration on third parties, such as creditors, or where it is otherwise deemed necessary." As Cardozo J. explained in Beatty v. Guggenheim Exploration Co., "[t]he equity of the transaction must shape the measure of relief." so

This debate over the constructive trust's institutional versus remedial nature has resulted in a lack of consistency in the application of constructive trusts in various

Sec A.J. McClean, "Constructive and Resulting Trusts - Unjust Enrichment in a Common Law Relationship - Pelıkus v. Becker" (1982) 16 U.B.C. L. Rev. 155 at 168.

Supra note 35.

ibid. at 64.

lbid. at 65 .

Ibid.

See D.M. Paciocco, "The Remedial Constructive Trust: A Principled Basis for Priorities over Creditors" (1989) 68 Can. Bar Rev. 315 at 319, n. 19:

To say that a trust is institutional is to suggest that it "arises as a necessary consequence ... whenever certain facts, which are recognized by law as being essential to the creation of the trust, are found to exist" and its existence automatically brings about pre-determined legal consequences. ... $\AA$ "remedy," on the other hand, is a particular consequence selected by an adjudieative body to give effect to a legal right which exists apart altogether from the remedy.

See Maudsley, "Proprietary Remedies," supra note 35 at 236-37.

As, for example, in Muschinski v. Dodds, supra note 35.

Supra note 1 at 381. 
common law jurisdictions. The so-called traditional English approach, which has generally looked for a fiduciary relationship before imposing a constructive trust, does not follow the same dictates as that in the United States, which is primarily restitutionbased. Further complicating these differences is the Canadian situation, which has drawn from both methodologies in the past.

The present status of the Canadian law of constructive trusts may be found in the Supreme Court of Canada's decision in Soulos." The judgments of McLachlin and Sopinka JJ. are indicative of the different approaches to constructive trusts used in Canadian jurisprudence. They also demonstrate how each of these approaches can view a common situation in quite different ways. While the majority decision in Soulos has somewhat clarified the current status of the constructive trust in Canadian law, it has left open a number of considerations that ought not be neglected if our understanding of the constructive trust is to be furthered.

\section{The avallability of Constructive Trusts in Canadian Law: SOULOS v. KORKONTZILAS}

The facts giving rise to the Soulos case occurred in 1984, when Nick Soulos retained real estate broker Fotios Korkontzilas to assist him in acquiring commercial properties. One property that Soulos was interested in acquiring - and the property that was the subject of contention in the case - was a building occupied by a branch of Soulos' bank, the significance of which will become evident later.

Soulos instructed Korkontzilas to offer Dominion Life, the vendor of the property, $\$ 250,000$ for the building. Dominion Life rejected the offer and put forward a counteroffer of $\$ 275,000$. Soulos rejected this counter-offer and instructed Korkontzilas to make another offer at $\$ 260,000$. Korkontzilas did not submit this new offer to the vendor. When Korkontzilas was advised by Dominion Life that it would accept $\$ 265,000$ for the property, Korkontzilas did not communicate the information to Soulos. Instead, Korkontzilas arranged for his wife, Panagiota, to purchase the property for $\$ 265,000$ under her maiden name. She then transferred the property into the names of Panagiota and Fotios Korkontzilas as joint tenants.

When Soulos asked Korkontzilas what had happened with the property, Korkontzilas told him to "forget about it." Korkontzilas said that the vendor was no longer interested in selling the property. He then told Soulos that he would find him a better property to purchase. When Soulos asked if Korkontzilas had influenced the vendor's change of heart, Korkontzilas denied having any effect on the vendor's decision. Soulos later discovered that Korkontzilas had purchased the property for himself. Soulos commenced an action against Korkontzilas for damages and, alternatively, to have the property conveyed to him. Soulos alleged that Korkontzilas breached his fiduciary duty, which gave rise to a constructive trust of the building for Soulos' benefit. 
Soulos abandoned his claim for damages prior to trial because the value of the property was not greater than what Korkontzilas had paid for it. ${ }^{32}$ He did, however, continue his claim based on constructive trust. Soulos sought to have the property transferred to him for the price that Korkontzilas paid for it, subject to adjustments for changes in value and losses incurred on the property subsequent to its purchase. Soulos claimed that the building had special significance to him because his bank was the tenant. In the Greek community that he belonged to, he contended that being the landlord of one's bank was a source of great prestige.

The significance of the Supreme Court of Canada's judgment in Soulos was its determination of the situations in which a constructive trust could be granted. Prior to Soulos, the Supreme Court had generally followed the precedent in Pettkus v. Becker, ${ }^{33}$ which held that there had to be an unjust enrichment of the person against whom the constructive trust was being sought before a constructive trust could be imposed. A three-step test, first enunciated in Pettkus and affirmed in Sorochan v. Sorochan, ${ }^{54}$ needed to be satisfied: there had to be an enrichment, a corresponding deprivation, and an absence of juristic reason for the enrichment. The majority and dissenting judgments in Soulos diverged on whether this prerequisite for the imposition of a constructive trust was universally applicable.

It should be noted that Soulos sought the constructive trust as a remedy for his claim of a breach of fiduciary obligation, not as a remedy for unjust enrichment. This characterization was a strategic manoeuvre on Soulos' part. Firstly, he did not have to demonstrate a transfer of the property from himself to Korkontzilas - which he could not have done, since it was purchased directly from the vendor. Equally significant was that Soulos did not have to address the fact that the property was now worth less than it was when Korkontzilas purchased it, which would bring into question whether Korkontzilas had been enriched by the purchase. Because of the manner in which the action was framed, Soulos' task was to convince the court that a constructive trust over the property was appropriate in the circumstances because of the non-monetary importance of the property to him. However, in convincing the court of this argument, he had to rebut the presumption that constructive trusts could be awarded only where there was unjust enrichment.

At trial, Anderson J. found that Korkontzilas had breached his duty of loyalty to Soulos. However, Soulos' claim of constructive trust was determined to be inappropriate because Korkontzilas had purchased the property at market value and, therefore, had supra note 4 at 218 , that the value of the property was less than what Korkontzilas had paid for it, there was no such statement in any of the earlier proceedings to this effect. This was noted in L.D. Smith, "Constructive Trusts - Unjust Enrichment - Breach of Fiduciary Obligations: Soulos v. Korkontzilas" (1997) 76 Can. Bar Rev. 539 at 541, n. 15. 
not been enriched by the transaction, ${ }^{35}$ nor had Soulos suffered any loss. ${ }^{36}$ At the Ontario Court of Appeal, ${ }^{57}$ Carthy J.A., for the majority, held that the imposition of a constructive trust in the circumstances was appropriate. The constructive trust was imposed for two purposes: to maintain the integrity of the fiduciary relationship by preventing Korkontzilas from gaining any advantage from his position as fiduciary; and, to deter Korkontzilas or other fiduciaries from acting immorally.

At the Supreme Court of Canada, McLachlin J., for the majority, ${ }^{58}$ agreed with the Court of Appeal's disposition of Soulos. She held that the constructive trust was an appropriate mechanism to condemn wrongful acts committed by fiduciaries and to maintain the integrity of relationships of trust. ${ }^{59}$ She described the constructive trust as "an ancient and eclectic institution imposed by law not only to remedy unjust enrichment, but to hold persons in different situations to high standards of trust and probity and prevent them from retaining property which in 'good conscience' they should not be permitted to retain." deterrent to persons in relationships of trust who sought to take advantage of that trust for their own purposes. McLachlin J. characterized this latter understanding of the constructive trust as a "real" or "institutional" trust, as opposed to the Pettkus v. Becker "remedial" trust. ${ }^{61}$ McLachlin J. explained that while Canadian courts had developed the constructive trust as a remedy for unjust enrichment in Pettkus v. Becker, they had never abandoned the institutional constructive trust that had been developed in England ${ }^{62}$ McLachlin J. also held that there was no need to found constructive trusts on existing fiduciary relationships. ${ }^{63}$

Soulos, Gen. Div., supra note 52.

* It is arguable, however, that Soulos did suffer a loss based on the transfer of Korkontzilas' loyalty to himself. The obvious difficulty with such a loss is in quantifying it. In addition, the trial court held that Soulos mitigated his loss by purchasing other properties. This latter conclusion is irrelevant to a claim of breach of fiduciary duty since fiduciary law is unconcemed with the concept of mitigation of losses. Traditionally, fiduciary law was concerned only with restoring wronged beneficiaries to the positions that they would have been in had no wrong occurred. Moreover, since fiduciaries are able to rely entirely on the good faith actions of their fiduciaries, there is generally no obligation for a fiduciary who knows of a loss 10 mitigate that loss. On this latter point, see, for example, Carl B. Potter Lid. v. Mercantile Bank of Canada Lid. (1980), 8 E.T.R. 219 (S.C.C.); Rotman, Parallel Paths, supra note 22 at 182, 190.

Soulas, $C$.A., supra note 52.

La Forest, Gonthier, Cory, and Major JJ. concurring.

Soulos, SCC, supra note 4 at 220-21.

Ibid. at 221.

As examples of such "institutional" trusts, McLachlin J. cited constructive trusts: arising on breach of fiduciary relationships; imposed to prevent an absence of writing from depriving a person of proprietary rights; to prevent a purchaser with notice from fraudulently retaining trust properties, and; to enforce secret trusts and mutual wills: see ibid. at 222.

As she explained, ibid. at 222-23, "cases such as Petukus v. Becker should not be taken as expunging from Canadian law the constructive trust in other circumstances where its availability has long been recognized." In making this assertion, she made reference to McClean, supra note 42 at 170; Paciocco, supra note 47 at 318; J.L. Dewar, "The Development of the Remedial Constructive Trust" (1982-4) 6 Est. \& Tr. Q. 312 at 332; and M.M. Litman, "The Emergence of Unjust Enrichment as a Cause of Action and the Remedy of Constructive Trust" (1988) 26 Alta. L. Rev. 407 at 416.

Soulos, SCC, ibid. at 222. 
McLachlin J. stated that the underlying basis of the constructive trust was "good conscience," specifically whether a person against whom the constructive trust was sought ought not, in good conscience, be entitled to retain the property in question. In formulating this approach to the constructive trist, she borrowed heavily from the dictum of Cardozo J. in Beatty v. Guggenheim Exploration Co., who explained that "[w] hen property has been acquired in such circumstances that the holder of the legal title may not in good conscience retain the beneficial interest, equity converts him into a trustee. ${ }^{\text {not }}$

McLachlin J. also relied on judgments rendered by Lord Denning M.R. in the early 1970s, in which he advocated the existence of "a constructive trust of a new model."6s One such judgment was Hussey v. Palmer, in which the Master of the Rolls explained that the constructive trust, "[b]y whatever name it is described ... is a trust imposed by law whenever justice and good conscience require it." ${ }^{166}$ He contended that this form of trust existed under "a liberal process, founded on large principles of equity."67 Soulos was not the first time that McLachlin J. had contemplated constructive trusts of this ilk. In a judgment rendered while she was a judge of the British Columbia Supreme Court, McLachlin J. had also raised the possibility of a constructive trust arising on the basis of "good conscience" independent of any unjust enrichment. ${ }^{68}$

The "good conscience" test expressed by McLachlin J. in Soulos was, in her opinion, a unifying basis for the various types of constructive trusts found to exist, including the "institutional" constructive trust and the Pettkus v. Becker remedial constructive trust. She explained that the good conscience standard "addresses not only fairness between the parties before the court, but the larger public concern of the courts to maintain the integrity of institutions like fiduciary relationships which the courts of equity supervised."69 Therefore, she held that the constructive trust could properly be used whenever the circumstances of a particular case warranted its imposition.

Although McLachlin J. held that good conscience was the basis for determining whether a constructive trust ought to be used in a particular situation, she expressed concern in her judgment over the generality of such a proposition:

Supra note 1 at 380.

Such as Eves v. Eves, supra note 17.

Supra note 17 at 1289.90 (C.A.). MeLachlin J. also cited some New Zealand precedents in support of this proposition, including Elders Pastoral Lid. v. Bank of New Zealand, [1989] 2 N.Z.L.R. 180 (C.A.) and Mogal Corp. v. Australasia Invessment Co. (In Liquidation) (1990), 3 N.Z.B.L.C. 101, although she did note that in the New Zealand case of Re Goldcorp Exchange Lid., supra note 17. the Privy Council rejected the creation of a constructive trust based on good conscience.

Hussey, supra note 17 at $1289-90$.

Yorkshire Trust Co. v. Empire Acceptance Corp. (Receiver of (1986), 22 E.T.R. 96 at 105-106 (B.C.S.C.). It should be noted that McLachlin J. did find, ibid. at 100, that an unjust enrichment had been made out in that case.

Soulos, SCC, supra note 4 at 226. 
Good conscience as a common concept unilying the various instances in which a constructive trust may be found has the disadvantage of being very general. But any concept capable of embracing the diverse circumstances in which a constructive trust may be imposed must, of necessity, be general. ${ }^{20}$

In an article written prior to Soulos, she had also been apprehensive about the lack of predictability resulting from liberal approaches to the application of equitable doctrines:

[T]he new, more liberal approach to equity has imported difliculties of its own. llow is the creative discretion of judges to be limited to avoid "palm tree justice"? What of certainty in law? And how are the new initiatives in the name of equity to be reconciled with traditional doctrines of contract and tort? ... The law should be predictable so that people can arrange their affairs in an orderly fashion; uncertainty brings its own injustices. But at the same time, the law must also be able to accommodate new and aberrant situations without producing injustice."

Because of her apprehension over the vagueness of the good conscience standard, McLachlin J. provided some parameters in Soulos for the imposition of constructive trusts based on good conscience. She identified four conditions which needed to be satisfied prior to imposing a constructive trust for wrongful conduct:

(1) The defendant must have been under an equitable obligation, that is, an obligation of the type that courts of equity have enforced, in relation to the activities giving rise to the assets in his hands;

(2) The assets in the hands of the defendant must be shown to have resulted from deemed or actual agency activities of the defendant in breach of his equitable obligation to the plaintiff;

(3) The plaintiff inust show a legitimate reason for seeking a proprietary remedy, either personal or related to the need to ensure that others like the defendant remain faithful to their duties; and

(4) There must be no factors which would render imposition of a constructive trust unjust in all the circumstances of the case; e.g. the interests of intervening creditors must be protected."

McLachlin J. agreed with the trial judge that Korkontzilas was Soulos' agent when he prepared the initial offer on the property in question. This agency relationship required Korkontzilas to inform Soulos about Dominion Life's communication that it

Jbid. A similar concern was expressed by Deane J. in Muschinski v. Dodds, supra note 35 at 67-8, who warned that, in attempting to use conscience as the basis of equitable remedies, courts must avoid "the formless void of individual moral opinion" that often masquerades under the description "equity and good conscience." Nole also Waters, "The Constructive Trust in Evolution," supra note 35 at 382. See also notes 122-25, infra.

" The Hon. B. MeLachlin, "The Place of Equity and Equitable Doctrines in the Contemporary Common Law World: $\Lambda$ Canadian Perspective" in D.W.M. Waters, ed., Equiry. Fiduciaries and Trusts 1993 (Toronto: Carswell, 1993) at 40 [hereinafter McLachlin, "The Place of Equity"]. Note also her comments, ibid. at 55: "... [T]he desire to do rough justice must be weighed against other interests, including a measure of certainty in the law, the legitimate expectations of parties, the right of parties to order their affairs by contrach, and the right of legislators to exercise their best judgment without fear of reprise."

7 Soulos, SCC, supra note 4 at 230. 
would accept $\$ 265,000$ for the property. The relationship between the two men was found to be fiduciary in nature. Soulos relied upon Korkontzilas' representations and entrusted Korkontzilas to act in his best interests in the finding of appropriate properties, the communication of offers to purchase and any counter-offers, and the disclosure of all other pertinent information relating to the properties. As Soulos' agent, Korkontzilas had a duty of loyalty to Soulos to act selflessly and in the latter's best interests when he purchased the property in question. Korkontzilas was, therefore, under an equitable obligation in relation to the activities giving rise to his acquisition of the property. Korkontzilas' obligations were deemed to have been initially breached when he failed to disclose to Soulos that he could have purchased the property in question for $\$ 265,000$. His acquisition of the property resulted from a further breach of duty. ${ }^{73}$

McLachlin J. also found that there were legitimate reasons in the circumstances to warrant a proprietary remedy. Soulos had a personal desire to own the property because of its prestige value. Therefore, he did not seek damages, but, rather, to be placed in the position he would have been in had the wrong perpetrated by Korkontzilas not occurred. This necessitated that he be awarded ownership of the property. While McLachlin J. held that this was reason enough to impose a constructive trust, she also found that a constructive trust was required in order to ensure that agents such as Korkontzilas and others in positions of trust remained faithful to their duty of loyalty. This latter concern had previously been expressed by the Supreme Court in Hodgkinson v. Simms. ${ }^{74}$ She explained that to not impose a constructive trust on the property would be tantamount to allowing real estate agents to wilfully breach their fiduciary obligations to their clients in situations where the agents do not eam a profit from the breach. Since she viewed this prospect as undermining the trust and confidence that underpin the institution of real estate brokerage, she held that it could not go unchecked by the court's equitable jurisdiction.

Finally, McLachlin J. held that there were no factors that would render the imposition of a constructive trust unjust in the circumstances. There was no prejudice to third parties, such as creditors, by the imposition of a constructive trust on the property. Such an order would also not result in unfair treatment to Korkontzilas, since Soulos would reimburse Korkontzilas for his purchase price of the property and indemnify him for losses suffered during the time that Korkontzilas owned the property. Consequently, McLachlin J. ordered that a constructive trust be imposed on the property, subject to the monetary adjustments described above.

In his dissenting judgment, Sopinka J., Iacobucci J. concurring, agreed that a fiduciary relationship existed between the parties, but disagreed as to the remedy awarded. He contended that the imposition of a constructive trust was a discretionary use of information obtained while in their positions as fiduciaries are in breach of their fiduciary obligations. See, for example, Regal (Hastings), supra note 8; CanAero, supra note 8. In addition, Korkontzilas may be seen to have breached his fiduciary duty by purchasing property that he knew Soulos wanted to buy while he was under a duty to act in Soulos' best interests. 
matter and, as such, any trial determination was entitled to appellate deference. Sopinka J. said that in order to overturn the trial judge's refusal to impose a constructive trust, it was necessary to show that the trial judge committed an error in principle. Sopinka J. deemed that no such error was committed. ${ }^{75}$ Referring to McLachlin J.'s good conscience test, Sopinka J. determined that the trial judge did consider the moral quality of Korkontzilas' actions and still found no reason to impose a constructive trust. Sopinka J. agreed with the trial judge's determination that, where there was no justification for ordering a constructive trust or other remedy, the morality of an act did not justify such an order. ${ }^{76}$

In addition to finding that there was no error in principle made by the trial judge, Sopinka J. maintained that constructive trusts are available only as remedies for unjust enrichment. He relied upon the following statement in La Forest J.'s judgment in $L A C$ Minerals to support this contention:

This Court has recently had occasion to address the circuinstances in which a constructive trust will be imposed in Hunter Engineering Co. v. Syncrude Canada Lid., [1989] I S.C.R. 426. There, the Chief Justice discussed the development of the constructive trust over 200 years from its original use in the context of fiduciary relationships, through to Petkus v. Aecker, [1980] 2 S.C.R. 834], where the Court moved to the modern approach with the constructive trust as a remedy for unjust enrichment. lle identified that Pestkus v. Becker, supra, set out a two-step approach. First, the Court determines whether a claim for unjust enrichmem is established, and then, secondly, examines whether in the circumstances a constructive trust is the appropriate remedy 10 redress that unjust enrichment. In Munter Engineering Co. v. Syncrude Canada Lid., a constructive trust was refused, not on the basis that it would not have been available between the parties ... but rather on the basis that the claim for unjust enrichment had not been made out, so no remedial question arose.

In the case at hand, the restitutionary claim has been made out. The Court can award cither a proprietary remedy, namely that Lac hand over the Williams property, or award a personal remedy, namely a monetary award. While, as the Chief Justice obscrved, "The principle of unjust enrichment lies at the heart of the constructive trust": see Pettkus v. Becker, at p. 847, the converse is nol true. The constructive trust does not lic at the heart of the law of restitution."

When these statements are regarded in the context of the LAC Minerals decision, it may be seen that they do not indicate that a constructive trust is available only where unjust enrichment has been made out.

While La Forest J. acknowledged the Supreme Court's move towards using the constructive trust as a remedy for unjust enrichment in $L A C$ Minerals, he did not state that the so-called institutional constructive trust must, as of consequence, be abandoned.

In her judgment, McLachlin J. held that the trial judge erred in failing to recognize the availability of a constructive trust in the absence of an enrichment by Korkontzilas.

$" \quad$ LAC Minerals v. Imternational Corona Resources Lid. (1989), 61 D.L.R. (4th) 14 at 48 (S.C.C.) [hereinafter LAC Minerals] as cited in Soulos, SCC, supra note 4 at 235 [emphasis added by Sopinka J. in Soulos]. 
Indeed, later in his judgment in $L A C$ Minerals, La Forest J. explicitly acknowledged the continuing existence of the institutional constructive trust in Canadian law:

[i]t is not the case that a constructive trust should be reserved for situations where a right of property is recognized. That would limit the constructive trust io its institutional function, and deny it the status of a remedy, its more important role."

In light of these comments, Sopinka J.'s characterization of La Forest J.'s judgment in $L A C$ Minerals is inappropriate. La Forest J.'s recognition of the institutional constructive trust as an existing use of constructive trusts expressly contradicts Sopinka J.'s assertion that constructive trusts only remedy unjust enrichment. ${ }^{79}$ What is especially curious is that in his own judgment in $L A C$ Minerals, Sopinka J. appeared to leave open the possibility of a constructive trust arising to prevent injustice, without any reference to the prerequisite of unjust enrichment. As he explained: "While the remedy of the constructive trust may continue to be employed in situations where other remedies would be inappropriate or injustice would resull, there is no reason to extend it to this case."180 Sopinka J. also relied on Pettkus v. Becker and Hunter Engineering Co. v. Syncrude Canada Ltd. ${ }^{81}$ to support his contention that the constructive trust was only available in situations of unjust enrichment.

Sopinka J. held that for a constructive trust to be found, a beneficiary had to have suffered some loss. He did not clarify what constituted a loss for such purposes. Did the beneficiary need to have been deprived of property that the beneficiary already possessed a right to, or must the beneficiary have only been deprived of an opportunity to acquire property or to earn profit?

Based on precedent established in cases such as Keech v. Sandford, ${ }^{\mathrm{B2}}$ Regal (Hastings), ${ }^{83}$ and CanAero, ${ }^{84}$ it is settled law that being deprived of an opportunity

LAC Minerals, ibid. at 50 [emphasis added].

As Paciocco explained, supra note 47 at 321:

... [W] hen the court in Pettkus said that the "principle of unjust enrichment lies at the heart of the constructive trust," it was speaking of that principle in the broad sense of "the ties of natural justice and equity," and not of the specific formula it was later to articulate for identifying the existence of a right to restitution.

LAC Minerals, supra note 77 at 76 [emphasis added] .

(1989), 57 D.L.R. (4th) 321 (S.C.C.). Interestingly, in this case, Dickson C.J.C.'s judgment did not state that the remedial constructive trust had superseded all other forms of constructive trust in Canada. As he explained, ibid. at 349:

Until the decision of this court in Peftkus v. Becker, the constructive trust was viewed largely in terms of the law of trusts ... In Pettkus v. Becker, the court moved to an approach more in line with restitutionary principles by explicitly recognizing constructive trust as one of the remedies for unjust enrichment. ... The court ... found that in the circumstances of the case a constructive trust was the appropriate remedy to redress the unjust enrichment. [Emphasis added]

Given the fact that Dickson C.J.C. said nothing further about the use of the constructive trust in Canadian law in his judgment, his judgment is not properly read as sanctioning the constructive trust as an instrument to be used only to remedy unjust enrichment.

Supra note 8.

lbid. 
is sufficient to constitute a loss that may be remedied by the imposition of a constructive trust. In those cases, fiduciaries' seizure of opportunities deemed to belong to their beneficiaries was sufficient to support a finding requiring the fiduciaries to hold the profits in question for their beneficiaries. The facts in Soulos - in which Korkontzilas seized an opportunity to purchase property when he was under a fiduciary duty to act in Soulos' best interests vis-à-vis the latter's acquisition of that property reveal an equivalent lost opportunity that ought to be similarly remedied.

The requirement that fiduciaries disgorge profits made from their seizure of such opportunities creates a constructive trust in which the profits are held by a fiduciary for the benefit of a beneficiary. Arguments to the contrary, supported by the precedent in Lister v. Stubbs, ${ }^{85}$ have been superseded, as, for example, by the Privy Council's decision in A.G. for Hong Kong v. Reid. ${ }^{86}$ In addition to the loss of opportunity, a beneficiary may also be seen to have suffered a loss via a fiduciary's transfer of loyalty to interests other than the beneficiary's. In other words, the act of breach itself is, itself, a loss, ${ }^{87}$ which satisfies the requirements established by Sopinka J. in Soulos.

Sopinka J. then turned his attention to the case of MacMillan Bloedel v. Binstead, ${ }^{88}$ which McLachlin J. had relied upon to support the imposition of a constructive trust, where the requirements established in Pettkus v. Becker had not been made out. In that case, a constructive trust was granted over secret profits which the corporation, because of its internal policy, could not have realized itself. Dohm J., as he then was, explained that a constructive trust may be imposed "even when the plaintiff has suffered no loss or deprivation. It is imposed not to balance the equities but to ensure that trustees and fiduciaries remain faithful and that those who assist them in the breaches of their duty are called to account." ${ }^{89}$ McLachlin J. explained that since MacMillan Bloedel could not have obtained the profits for itself and, consequently, could not have suffered a deprivation, the test in Pettkus could not be satisfied. She contended that the British Columbia Supreme Court's imposition of a constructive trust to prevent Binstead from retaining the profits meant that Pettkus did not abolish the institutional constructive trust.

Ibid.

(1890), 45 Ch.D. 1 (C.A.). In this case, it was determined that an agent who breached his fiduciary duty to his principal by taking secret profits from a supplier held the secret profit for his principal's benefit, but did not hold that money in trust.

[1994] A.C. 324 (P.C.). For a comprehensive analysis of the Reid decision and its effect on the precedent in Lisser v. Stubbs, sec M. Cope, "Ownership, Obligation, Bribes and the Constructive Trust" in M. Cope, ed., Equity: Issues and Trends (Annandalc, N.S.W.: Federation Press, 1995) [hereinafter Cope, "Ownership, Obligation, Bribes"]. It may also be suggested that the LAC Minerals decision, supra note 77 at 50, in which La Forest J. explained that a constructive trust does not only recognize existing rights of property, but may actually create such rights, also supports a rejection of the principles in Lister v. Stubbs: see Oosterhoff \& Gillese, supra note 28 at 374-75.

A similar point is made in Elias, supra note 20 at 74-75.

(1983), 14 E.T.R. 269 (B.C.S.C.).

Jbid. at 302. 
In contrast to McLachlin J.'s interpretation, Sopinka J. viewed the Binstead case as one of unjust enrichment. He explained that Binstead, the manager of log trading for MacMillan Bloedel (and a fiduciary to the corporation), breached his duty to the corporation by selling surplus logs to a company in which he held a secret interest. Even though MacMillan Bloedel could not have earned the profits itself, Sopinka J. stated that the corporation still suffered a deprivation. As he explained, "[t]he deprivation is represented by the monies obtained by the fiduciary as a result of infringing the rights of the plaintiff." King ${ }^{91}$ and CanAero, ${ }^{92}$ he contended that merely because MacMillan Bloedel could not have obtained the profits did not prevent a finding of unjust enrichment.

While Sopinka J. is correct that a person may be unjustly enriched where another person does not suffer any deprivation, the precedents he relied on contemplate the disgorgement of profits. In those situations, there is no need to demonstrate that the beneficiary suffered a loss, only that the fiduciary obtained an improper gain. ${ }^{93}$ The standard for imposing liability in these circumstances is, therefore, different than that required in Pettkus. The test in Pettkus requires both an enrichment and a corresponding deprivation. The fact that Binstead obtained an improper gain does not necessarily entail that MacMillan Bloedel was deprived. Sopinka J.'s insistence that MacMillan Bloedel's deprivation is represented by the monies obtained by Binstead commingles the requirements of enrichment and corresponding deprivation established in Pettkus. If these requirements can be commingled, why could it not be said that Soulos' loss of the ability to own the building, housing his bank, is represented by Korkontzilas' acquisition of the building in breach of his duty to Soulos? ? $^{94}$

Sopinka J. held that for there to have not been a deprivation or unjust enrichment in Binstead, Binstead's self-dealing could not have resulted in any secret profit. Sopinka J. found that the secret profit resulted in an unjust enrichment which justified the imposition of a constructive trust, whether or not the court relied upon such enrichment to found such imposition. ${ }^{95}$ He held that for an enrichment to exist in Soulos, there had to be "pecuniary advantages accruing to the appellants from the purchase of the

Soulos, SCC, supra note 4 at 239.

[1948] 2 All E.R. 27 (K.B.), afTd[1949] 2 All E.R. 68 (C.A.), afrd [195I] I All E.R. 617 (H.L.). Supra note 8.

Indecd, fiduciary law concentrates exclusively upon the actions of fiduciaries to ensure that they ascribe to the standard of conduct required of them. It is generally unconcerned with the actions of beneficiaries, save for the possible application of laches or acquiescence, where appropriate. Note the comments by Smith, supra note 52 at 548 :

[l:Jven on Sopinka's J. view of the law, it is unclear why the plaintiff was not entitled to his trust. Speaking of cases where trusts have been granted, the leamed judge said, "The deprivalion [to the plaintim] is represented by the monies obtained by the fiduciary as a result of infringing the rights of the plaintiff:" Is there any difference between monies and other property? If not, why was the estate obtained by the fiduciary Korkontzilas, as a result of infringing the rights of the plaintiff, not viewed as a deprivation of Soulos which would support a trust remedy?

Soulos. SCC. supra note 4 at 239. 
property." 96 Since there was no such advantage, he concluded that there was no enrichment, unjust or otherwise.

Although Soulos did not put forward an unjust enrichment argument, it is arguable that such an argument could have succeeded under the test in Pettkus. Sopinka J.'s requirement that enrichments and deprivations contemplated by that test must be monetary is inappropriately restrictive. ${ }^{97}$ Requiring that enrichments and deprivations must be monetary brings into question the imposition of a constructive trust in the $L A C$ Minerals case. In LAC Minerals, LAC, a senior mining company, purchased property using confidential information it had obtained from Corona, a junior mining company. LAC obtained the information during negotiations between the two companies to form a joint venture to develop a number of properties, including the property in question. LAC then surreptitiously purchased the property and began to develop it on its own. Corona initiated proceedings against LAC for breach of contract, breach of confidence, and breach of fiduciary duty.

The Supreme Court of Canada found that LAC breached its duty of confidence to Corona and a constructive trust was imposed on the property for Corona's benefit. This constructive trust was imposed notwithstanding the absence of any indication that LAC had paid less than fair value for the property. The purpose of the constructive trust in LAC was to take away profits resulting from LAC's wrongful act. Ought the Soulos scenario, in which Korkontzilas paid market value (at the time) for the property, using information obtained while under a fiduciary obligation to act in Soulos' interests regarding the purchase of the property, be regarded any differently? The fact that LAC obtained the property, even though it paid fair value for it, was deemed to have conferred a benefit on LAC that it could not properly retain. The use of the constructive trust in $L A C$ Minerals, therefore, appears to affirm the suggestion that an enrichment may exist in the absence of a monetary gain.

While the $L A C$ Minerals decision indicates that it is possible to have non-monetary enrichments that are deserving of remedy via the constructive trust, what about nonmonetary deprivations? It may be legitimately argued that these deprivations are also worthy of remedy, including that provided by the constructive trust. A beneficiary of a fiduciary relationship may be seen to suffer a non-monetary deprivation where, for example, the loyalty of the fiduciary is transferred to interests other than the beneficiary's own. If this transfer of loyalty results in the fiduciary purchasing a property, for fair value, that the fiduciary was negotiating for on behalf of the beneficiary (as in Soulos), then it may be seen that the beneficiary was deprived by the transfer of loyalty and the lost opportunity to acquire the property. The deprivation under these circumstances, like the enrichment in LAC Minerals, may properly fit within the conditions for unjust enrichment spelled out in Pettkus v. Becker.

7 As suggested in the text accompanying note 94 . 
Interestingly, in Soulos, Sopinka J. articulated the possibility that pecuniary gains may not always be determinative of an enrichment or deprivation. ${ }^{98}$ Such a situation could exist where a property was unique or otherwise difficult to value - in a manner similar to the awarding of specific performance in contract.99 In the Soulos case, however, Sopinka J. found that the property in question was not unique and thus did not fall within this exception. While there may have been personal motivations behind Soulos' attempt to purchase the property, those were deemed irrelevant to an assessment of the value of the property.

From Sopinka J.'s statements, it would appear that his exception to the requirement of monetary enrichment necessary for imposing constructive trusts applies only where the uniqueness or difficulty in valuing the property in question may be objectively recognized. However, his discussion of the precedent in Lee v. Chow, ${ }^{100}$ a case relied on at trial, suggests that this is not so. In Lee, a constructive trust was declared over residential property that had been purchased by a real estate agent under circumstances not dissimilar from the events in Soulos. ${ }^{101}$ Yet, in Lee, there was said to be an increase in the value of the property subsequent to the agent's clandestine purchase of it. ${ }^{102}$

The trial judge in Soulos considered the Lee precedent and distinguished Soulos from Lee on three bases. The trial judge held that in Lee, there was a dependence by Lee on the defendant agent, Chow, that was held to be lacking in Soulos. ${ }^{103}$ Also, the property in question in Lee was residential and met the specific requirement of the plaintiff - as opposed to being a commercial property whose value was held to have existed only as an investment - thus making it unique. ${ }^{104}$ Finally, it was held that the purchase price of the property in Lee "appeared" to represent a bargain, whereas

Soulos, SCC, supra note 4 at $241-42$.

sbid.

(1990), 12 R.P.R. (2d) 217 (Ont. S.C.) [hereinatter Lee].

Lee had retained Chow to act as his agent in the purchase of a residential homc. He communicated to Chow the range of price he was willing to pay, the area he wanted to live in, and a description of the type of home he sought. After a number of offers and counter-offers on a particular property, Chow purchased it for herself. Lee sought a constructive trust of the property for his benefit based on Chow's breach of fiduciary duty. The action was successful and the property was held to be conveyed to Lee for the price that Chow had paid for it.

Soulos, SCC, supra note 4 at 242 . No mention of any increase was made in the reported Lee judgment.

Soulos, Gen. Div., supra note 52 at 70.

Jbid. Interestingly, Sopinka J. also held in Soulos, SCC, supra note 4 at 242, that the property in question in Lee "had unique qualities which helped justify a constructive trust" though there was no mention of the uniqueness of the property in the Lee judgment itself. While many houses and/or their properties are unique, there is nothing in the judgment in Lee (aside from Lee's request to find a "new home on a large lot in the Bayview area at a price in the range of $\$ 1,000,000$ ": Lee, supra note 100 at 218 ) that suggests that the property in question was, in any way, uniquely suited to Mr. Lee's needs. In fact, there are a number of homes on large lots in the area in question that would have satisfied Lee's requirements, which mitigates against Sopinka J.'s finding of "uniqueness" in Lee versus its absence in Soulos. 
there was no such bargain in Soulos. ${ }^{105}$ Sopinka J. agreed with the trial judge's distinguishing of Lee from the facts in Soulos. ${ }^{106}$

Notwithstanding these findings, there are a number of difficulties in distinguishing the facts in Lee from the circumstances in Soulos. The Lee judgment indicates that Lee relied on Chow for the latter's advice during negotiations over the property in question and had advised Chow to "keep an eye on the house for them [Lee and his wife] and advise of further developments" after their last offer was rejected. ${ }^{107}$ This relationship is arguably no different than the standard relationship between prospective purchasers and their agents, in which the former rely on the latter to present offers, receive counter-offers, and to provide advice. A similar situation is apparent in Soulos, where Soulos relied on Korkontzilas to present offers and receive counter-offers on the property in question. ${ }^{108}$

Secondly, the materiality of characterizing the Soulos property as an investment property to the availability of the constructive trust as restitution for Korkontzilas' breach of duty is not at all evident. The unique quality of a property ought not to be affected by a determination that it is sought for personal or investment purposes. Like a residential home, an investment property may have sufficiently "unique" qualities such as its location, architecture, or expandability - to ensure that it could not easily be substituted by another property. In attempting to distinguish between properties purchased for residential use versus investment, Sopinka J.'s argument also fails to appreciate that a key factor in the acquisition of a residential property is its resale value (which indicates that such a purchase is also made, at least in part, as an investment).

Lastly, the finding in Soulos that the acquisition price in Lee represented a bargain was apparently arrived at because there were offers and counter-offers made on the property in question. How the Lee situation is distinguishable from Soulos, where there was an offer and counter-offer on the property in issue, is not evident from either the trial judgment or that rendered by Sopinka J. It may be seen from the Lee case, therefore, that a property may be considered unique and difficult to value because of a plaintiff's subjective reasons for wanting to acquire it. The question remains whether Lee's desire for a "new home on a large lot in the Bayview area at a price in the range of $\$ 1,000,000$ " ought to be seen as sufficiently different than Soulos' desire to own the building that housed his bank to warrant a finding of constructive trust.

\section{THE IMPLiCations Of SOULOS}

From the Soulos decision, the Supreme Court has confirmed that constructive trusts may be imposed not only as remedies for unjust enrichment, as in the Pettkus v. Becker line of cases, but also where good conscience dictates that they be used to correct

Itax Soulos, Gen. Div. supra note 52 at 54-55; Soulos, SCC, supra note 4 at 217-18. 
injustices. Thus, it indicates that the law of constructive trusts in Canada is not restricted to a role as a remedy for unjust enrichment, but includes other forms.

This finding is supported by academic commentary. A number of commentators who examined the development of the constructive trust as a remedy for unjust enrichment in Pettkus v. Becker concluded that the Court in Pettkus did not intend to establish a new, unitary role for the constructive trust. ${ }^{109}$ If Petikus was intended to have such an effect, Waters, for one, has properly argued that the abolition of non-Pettkus forms of constructive trust required something more than the Supreme Court of Canada's silence on the matter. ${ }^{110}$ Indeed, in no case prior to Soulos did the Supreme Court expressly hold that the Penkus form of constructive trust had replaced all other forms of constructive trusts in Canada. In fact, in her judgment in Rawluk v. Rawluk, McLachlin J. mentioned the existence of "other types of constructive trusts" in addition to that established in Pettkus. ${ }^{\prime \prime}$

In spite of its discussion of the institutional versus remedial character of the constructive trust and what constitutes enrichment, it is suggested that the key point of the Soulos judgment is its sanction of the constructive trust based on good conscience. While the "good conscience" rationale espoused by McLachlin J. has the potential to multiply the use of constructive trusts in Canada, it also presents the opportunity for significant debate over the future of the constructive trust in Canadian law. It will now be left to lower courts and academic commentators to discuss what was meant by the Supreme Court's affirmation of constructive trusts arising on the basis of good conscience. Is this form of constructive trust essentially the same as the "constructive trust of a new model" proposed by Lord Denning M.R. in the early 1970s? Alternatively, is it, or will it become, a basis for categorization in a manner akin to the traditional English institutional constructive trust?

Lord Denning M.R.'s constructive trust of a new model was based, in part, on dictum of Lord Diplock in Gissing v. Gissing, who explained that relief is available to a beneficiary whenever a trustee has acted in such a fashion that it would be inequitable to allow the trustee to deny the beneficiary an interest in land so acquired..$^{112}$ This form of constructive trust has attracted a significant number of critics. Lord Denning M.R.'s open-ended explanation that this trust is "imposed by law ... whenever justice and good conscience require it" using a process "founded on large principles of equity"'13 has only heightened the opposition to this form of constructive trust.

Sce, for example, Paciocco, supra note 47 at 320; McClean, supra note 42 at 168; Litman, supra note 62 at 415-18. In contrast, see K.B. Farquhar, "Case Comment - Special Relationship Domestic Services - Remedial Constructive Trust: Peter v. Beblow" (1993) 72 Can. Bar Rev. 538 at 550-52.

Wuters, "The Constructive Trust in Evolution," supra note 35 at 377.

(1990), 65 D.L.R. (4th) 161 at 185 (S.C.C.). McLachlin J. held that since the facts in Rawiuk supported a finding of unjust enrichment, it was not necessary to consider if those other types had been abolished.

[1971] A.C. 886 at 905 (H.L.).

Hussey v. Palmer, supra note 17 at 1289-90. 
A leading English text on trusts suggests that adopting Lord Denning's new-model constructive trust "would effect a complete swing on the pendulum so far as the principles of English law concerning constructive trusts are concerned."114 Others criticize Lord Denning for ignoring the context in which Lord Diplock made his remarks in Gissing v. Gissing. "'s One critic has gone so far as to suggest that this form of constructive trust is not based upon principle at all, but is result-oriented: "It is possible to read into recent decisions a rule that in cases where the plaintiff ought to win, but has no legal doctrine or authority to support him, a constructive trust in his favour will do the trick." 116 However, the majority of critics have argued that the new-model constructive trust is unprincipled and unpredictable, thus providing no measure of certainty as to how, or when, it ought to be used. ${ }^{17}$ Indeed, it has been suggested that "[a] 'just and equitable' test, standing alone and unsupported by expressed reasons why one result is more just than another, appears visceral rather than cercbral." 18 It may be seen that criticism of the new-model constructive 1rust is based largely on perceptions of it as idiosyncratic and, therefore, unpredictable. Such criticisms are derived from, and often quote, in part or full, the seventeenth century English jurist John Selden's infamous critique of the practices of the Court of Chancery:

Equity is $\wedge$ Roguish thing. for Law wee have a measure know what to trust too. I:quity is according to $y^{e}$ conscience of him $y^{\prime}$ is Chancell'", and as $y^{\prime}$ is larger or uarrower soe is equily 'lis all one as if they should make $y^{c}$ Standard for $y^{c}$ measure wee call $A$ font, to be $y^{*}$ Chancellors foot; what an uncertain measure would this be; One Chancello' ha's a long foot another $\Lambda$ short foot a third an indifferent foot; tis $y^{*}$ same thing in $y^{*}$ Chancello's Conscience.""

Selden was not the first person to express such concerns about the jurisdiction of Equity. In the sixteenth century, one critic made the following statements:

For on the one part it is thought as hard a thing to prescribe to Equitie any certainc bounds, as it is to make any one general Law to be a meet measure of Justice in all particular cases. And on the other side it is said, that if it be not known beforchand in what cases the Chancellour will reach forth his helpe, and where not, then neither shall the subject bee assured how, or when he may possess his owne in peace, nor the Practizer in Law be able to inform his client what may become of his action. ${ }^{2: "}$

Martin, Hanbury and Martin. Modern Equiny, 15th ed., supra nole 28 at 318.

Sec supra note 112 and its accompanying text. Some of these criticisms are documented in Cope. supra note 28 at 812-3. See also Oakley, supra note 28 at 39, and, generally, at 39-47.

Maudsley, "Constructive "Trusts," supra note 3 at 123.

For example, in Cope, supra nole 28 at 813 , the new-model constructive trust is said to be open to criticism, since "it is difficult to know in what circumstances the constructive trust will arise because of the emphasis that this approach places on the individual judges' idea of justice and good conscience." See also P.H. Pettit, Equity and the Law of Trusis, Goli ed. (London: Butterworllis, 1989) at 166, where the author states that "one of the main difficultics in relation to this development has been to know in what circumstances a constructive trust would be found: it is difficult to know what the law is when it relies to much on the individual judge's idea of justice and good conscience"; set also Martin, supra note 28 at 323.

See R.E. Scane, "Relationships 'Tantamount to Spousal,' Unjust linrichment, and Constructive Trusts" (1991) 70 Can. Bar Rev. 260 at 297.

F. Pollock, ed., Table Talk of John Selden (London: Quaritch, 1927) at 43.

Lambarde, Archeion, as quoled in Scant, stipra note 118 at 261, n.2. 
While many legal commentators vociferously condemned the new-model constructive trust, many judges expressed these same thoughts. In Pettkus v. Becker, Martland J. suggested that Lord Denning M.R.'s new-model constructive trust "would clothe Judges with a very wide power to apply what has been described as "palm tree justice"121 without the benefit of any guide-lines."122 Martland J.'s criticism in Pettkus was echoed by La Forest J. in LAC Minerals, where he stated "I do not countenance the view that a proprietary remedy can be imposed whenever it is 'just' to do so, unless further guidance can be given as to what those situations may be."123 Similarly, in the High Court of Australia's judgment in Muschinski v. Dodds, Brennan J. held that "[t]he flexible remedy of the constructive trust is not so formless as to place proprietary rights in the discretionary disposition of a court acting according to vague notions of what is fair." 24 Meanwhile, in New Zealand, Mahon J. commented in Carly v. Farrelly that "[i]t cannot be sufficient to say that wide and varying notions of fairness and conscience shall be the legal determinant. No stable system of jurisprudence could permit a litigant's claim to justice to be consigned to the formless void of individual moral opinion."12s

Although Equity has long faced criticism of its adjudicative process, malleable doctrines, and institutions (such as the constructive trust) by those demanding greater jurisprudential certainty, the original function of Equity as a court of conscience should not be forgotten. ${ }^{126}$ The jurisdiction of Equity was created in order to mitigate the rigours of the law. ${ }^{127}$ As was explained in Dudley v. Dudley:

Now cquity is no part of the law, but a moral virtue, which qualifies, moderates, and reforms the rigour, hardness, and edge of the law, and is an universal truth; it does also assist the law where it is defective and weak in the constitution (which is the life of the law) and defends the law from crafty evasions, delusions, and new subtilties [sic], invented and contrived to evade and delude the common law, whereby such as have undoubted right are made remediless; and this is the office of equity, to support and protect the common law from shifts and crafty contrivances against the justice of the law. Equity therefore does not destroy the law, nor create it, but assist it."2

The notion of "palm tree" justice is explained in D.J. Hayton, The Law of Trusts (London: Sweet \& Maxwell, 1989) at 151 as "justice disposed by wise men, 'cadi, sitting under palm trees acting according to their notions of justice and faimess."

Supra note 5 at 262 . His concem was that this model provide no guidelines and could only result in subjective determinations. As he explained, ibid. at 262: "By what test is a Judge to determine what constitutes unjust enrichment? The only test would be his individual perception of what he considered to be unjust." See also Martland J.'s judgment in Rathwell v. Rathwell (1978), 83 D.L.R. (3d) 289 at 296 (S.C.C.).

LAC Minerals, supra note 77 at 51.

Supra note 35.

[1975] I N.Z.L.R. 356 at 367 (S.C.).

For background on the origins and history of Equity, see D.M. Kerly, An Historical Sketch of the Equilable Jurisdiction of the Court of Chancery (Cambridge: Cambridge University Press, 1890); G.B. Adams, "The Origins of English Equity" (1916) 16 Columbia L. Rev. 87; G.B. Adams, "The Continuity of English Equity" (1916-17) 26 Yale L.J. 550; and W. Ashbumer, Principles of Equity (London: Butterworths, 1902).

127 See Re Vandervell's Trusts (No. 2), [1974] I Ch. 269 at 322 (C.A.). 
Equity - in theory, if not in practice ${ }^{129}$ - was a response to the overly rigid taxonomy that had overtaken the common law and wrongfully deprived many of justice. It was designed to take a more individualized approach to particular cases, meting out justice that was appropriate to the specific needs of individual facts. ${ }^{130}$

As a court of conscience, the Court of Chancery had jurisdiction to deal with matters based on large and liberal notions of faimess and justice, as opposed to the rigid taxonomy of the common law. ${ }^{131}$ In developing its jurisdiction, it created a number of infamous maxims that continue to the present day. These maxims include: "Equity acts on the Conscience" 132; "He who seeks Equity must do Equity"133; "He who comes into Equity must come with clean hands" 134; "Equity will not permit a statute to be used as a cloak for fraud"135; "Equity looks to the substance and intent rather than to the form,"136 and; "Equity imputes an intention to fulfil an obligation."137

These equitable doctrines provided guidelines for the administration of justice in Chancery. The Lord Chancellor did not have the power to determine the outcome of equitable actions on a whim. ${ }^{138}$ While he was not bound by rigid rules, he was guided by equitable principles and precedent. These principles were illuminated by broad maxims, such as those illustrated above, that could be adapted as circumstances required. In many ways, Equity may be seen to have developed much as the common law had - through the creation of principles and doctrines which became the precedents for subsequent considerations of similar facts. The difference between the

129 See the discussion of Lord Eldon L.C.'s view of Equity, infra.

170 See S. Toulmin, "Equity and Principles" (1982) 20 Osgoode Hall L.J. I at 8-9:

[E]quity requires not the imposition of uniformity or equality on all relevant cases, but rather reasonableness or responsiveness in the application of general rules to individual cases. Equity means doing justice with discretion; around, in the interstices of, and in the areas of conflict between our laws, rules, principles and other general formulae. It means being responsive to the limits of all such formulae, to the special circumstances in which one can properly make exceptions, and to the trade-offs required where different formulae conflict.

13. In 16 Halsbury's Laws of England, 4th ed. (reissue) (London: Butterworths, 1976) at para. 1204, [hereinafter Halsbury's Laws of England] it is said that "[e]arly authorities refer to "conscience," "reason" and "good faith" as the principles which guided the Court of Chancery, and the term "equity" implies a system of law which is more consonant than the ordinary law with opinions current for the time being as to a just regulation of the mutual rights and duties of men living in a civilised society."

132 See Penn v. Lord Bahtimore (1750), I Ves. Sen 444 (Ch.); and Elwing v. Orr-Ewing (1883), 9 App. Cas. 34 at 40 (H.L.): "The Courts of Equity in England are, and always have been, Courts of conscience ..."

Davis v. Duke of Marlborough (1819), 2 Swan 108 at 157 (Ch.); Halsbury's Laws of England, supra note 131 at para. 1303.

194 Fitzroy v. Gwillim (1786), 1 Term Rep. 153 (Ch.).

135 See the references supra note 41.

136. As Romilly M.R. explained in Parkin v. Thorold (1852), 16 Beav. 59, 51 E.R. 698 at 701: "If [a coun of equity] find that, by insisting on the form, the substance will be defeated, it holds it to be inequitable to allow a person to insist on such form, and thereby defeat the substance."

117 See Lechmere v. Lady Lechmere (1735), Cas T Talb 80, 25 E.R. 673 (Ch.).

111. As explained in Halsbury's Lasus of England, supra note 131 at para. 1204, "... [t]here was never a time in the history of the court when the Chancellor was at liberty to follow generally either his own, or professional or common opinions as to what was right and convenient." 
two systems was that Equity neither blinded itself to the facts nor applied its principles as rigidly as did the common law.

The innate human tendency to gravitate towards the familiar and the orderly, when taking the form of the quest for jurisprudential certainty, created the juristic orthodoxy called stare decisis. In the process of beautifying stare decisis, the legitimate, and relevant, question "Who creates precedent where there is none and by what means?" has often been overlooked. Is the notion of legal precedent not itself premised upon the ideal of deductive reasoning influenced by abstract principles of justice and faimess?

While the Lord Chancellor did not have jurisdiction to render justice capriciously, he did possess a considerable amount of discretion. That discretion, combined with the malleability of equitable doctrines, allowed him to mould the principles of Equity to fit the unique requirements of specific situations. ${ }^{139}$ While these equitable doctrines provided the Lord Chancellor with guidance and established the parameters of his jurisdiction, they did not detract from the inherent flexibility that remained at the heart of Equity. ${ }^{1+0}$ This vision of Equity is not always shared. Some have stated that the jurisdiction of Equity had become as rigid and technical as the common law. ${ }^{141}$ As corroboration for this assertion, the words of Lord Eldon L.C. in Gee v. Pritchard are offered as evidence:

The doctrines of this Court ought to be as well settled and made as uniform almost as those of the common law, laying down fixed principles, but taking care that they are to be applied according to the circumstances of cach casc ... Nothing would inflict on me greater pain, in quitting this place, than the recollection that I had done any thing to justify the reprosch that the equity of this Court varies like the Chancellor's foot. ${ }^{\text {Ha }}$

While this statement has sometimes been understood to mean that Equity had become rigid and structured like the common law, such an interpretation overstates the case. Lord Eldon appears simply to have advocated the need for more principled guidelines for the application of equitable doctrines without deviating from Equity's inherent flexibility. Thus he sought to "[lay] down fixed principles ... taking care that they are to be applied according to the circumstances of each case." In this way, the application of equitable principles would be better understood while continuing to be appropriately contoured to the unique circumstances of individual cases.

This latter interpretation of Lord Eldon's dictum in Gee v. Prilchard is reflected in the judgment of Dickson J., as he then was, in Pettkus v. Becker: "The great advantage of ancient principles of equity is their flexibility: the judiciary is thus able to shape

See P.M. Perell, The Fission of Law and Equity (Toronto: Butterworths, 1990) at 10-12. I am indebted to Mr. Perell's work for a number of the sources quoled below.

In opposition, see R. Pound, "Ilie Decadence of Equity" (1905) 5 Col. L. Rev. 20 (hereinafler Pound, "Tlie Decadence of Equity"): R. Pound, "The lind of Law as Developed in I.egal Rules and Doctrines" (1914) 27 Harv. L. Rev. 195, esp. at 218-19.

See Pound. "The Decadence of Equily," ibid. at 27; Lord A. Denning, Landmarks in the Law (London: Butterworths, 1984) at 81.

(1818), 2 Swan 402 at 414, as quoted in Denning, supra note 141 at 81. 
these malleable principles so as to accommodate the changing needs and mores of society, in order to achieve justice." 143 While, as Dickson J. stated, equitable principles may be shaped to fit the changing needs and mores of society, if there was no understanding of what those principles were - such as would be the case under an unarticulated "Chancellor's foot" regime - there would be no clay with which to sculp.

With the so-called "fusion" of law and equity through the merger of legal and equitable jurisdictions, ${ }^{144}$ some of Equity's inherent flexibility has been whittled away through the imposition of more rigid classifications and formulae. This result is unfortunate, for the original rationale for the merger of legal and equitable jurisdictions was procedural and not substantive. ${ }^{145}$ This assertion is supported by statements made by Lord Selbourne, L.C., who introduced the legislation, and Attorney-General Sir John Coleridge, who promoted it. Lord Selbourne said:

It may be asked ... why not abolish at once all distinction between law and equity? I can best answer that by asking another question - Do you wish to abolish trusts? If trusts are to continuc, there must be a distinction between what we call a legal and an equitable estate ... The distinction, within certain limits, between law and cquity, is real and natural, and it would be a mistake to suppose that what is real and natural ought to be disregarded. ${ }^{1 / 4}$

Coleridge, meanwhile, expressed essentially similar sentiments:

To talk of the fusion of Law and Equity was to talk ignorantly. Law and Equity were two things inherently distinct ... All they could do was to secure that the suitor who went to one Court for his remedy should not be sent about his business without the relief he could have got in another Court. ${ }^{147}$

Unfortunately, the procedural versus substantive basis for the merger of legal and equitable jurisdictions has been forgotten over time, being buried in incorrect assumptions about the meaning of the phrase "the fusion of law and equity." 148 This has resulted in a commingling of legal and equitable principles, with the potential for

Pettkus v. Becker, supra note 5 at 273. See also La Forest J. in Canson Enterprises LId. v. Boughion \& Co. (1991), 85 D.L.R. (4th) 129 at ISI (S.C.C.) [hereinafter Canson], where he stated that "the maxims of equity can be flexibly adapted to serve the ends of justice as perceived in our days. They are not rules that must be rigorously applied but malleable principles intended to serve the ends of fairness and justice."

See Judicature Act, 1873 (U.K.), 36 \& 37 Vict., c. 66; Judicature Act, 1875 (U.K.), 38 \& 39 Vict., c. 77.

See Judicature Commission, First Report of the Commissioners (London: George Edward Eyre and William Spatiswoode, 1869) at 6-7, as quoted in Perell, supra note 139 at 20, where the Commission stated that, in spite of the "transfer or blending of jurisdiction," created by then-recent legislation, "old mischief still remains" which required the creation of "a tribunal invested with full power of dealing with all the complicated rights and obligations ... and of administering complete and appropriate relief, no matter whether the rights and obligations involved are called Iegal or equitable." Sec also Salt v. Cooper (1880), 16 Ch.D. 544 at 549; affd 16 Ch.D. 556 (C.A.); Pettit, supra note 117 at 9-10.

As quoted in R.P. Meagher, W.M.C. Gummow, \& J.R.F. Lehane, Equity. Doctrines and Remedies, 2d ed. (Sydney: Butterworths, 1984) at 45.

As quoted, ibid. at 38.

See, for example, Canson, supra note 143. 
unfortunate results. Concern over precisely this sort of occurrence is what led Professor Ashburner to pen the famous words "the two streams of jurisdiction, though they run in the same channel, run side by side and do not mingle their waters." ${ }^{199}$ Although it is important for a system of law to generate rules and practices to provide a greater measure of doctrinal certainty, ${ }^{150}$ it is also important for such a system to retain needed flexibility in order to deal with unforeseen or unique circumstances. ${ }^{151}$ While W.S. Holdsworth once said that it was better to have a system of law that was too rigid than no system at all, ${ }^{152}$ that does not mean that that system must be rooted in taxonomy rather than broad principles and judicial discretion.

What is truly ironic is that one of the chief criticisms of the constructive trust based on good conscience, which is a purely equitable concept, is that it is premised on large and liberal notions of faimess and justice, as opposed to the rigid taxonomy of the common law. ${ }^{133}$ Should an equitable concept not rely on equitable principles? As suggested earlier, the perceived lack of principled application of equitable doctrines is often exaggerated by those attempting to contrast Equity's flexible, situation-specific oriented procedure with common law taxonomy.

Ashbumer, supra note 126 at 23. Note, however, Lord Diplock's comments in United Scientific Holdings Lid. v. Burnley Council, [1978] A.C. 904 at 925 (H.L.) [hereinafter United Scientific Holdings], where he said, in response to Ashburner's vision of Equity, that:

My Lords ... this metaphor has in my view become both mischievous and deceptive. The innate conservatism of English lawyers may have made them slow to recognise that by the Supreme Court of Judicature Act 1873 the two systems of substantive and adjectival law formerly administered by courts of law and Courts of Chancery ... were fused. If Professor Ashbumer's fluvial metaphor is to be retained at all, the waters of the confluent streams of law and equity have surely mingled now.

Lord Diplock's statements in the United Scientific Holdings case are indicative of the misperception of the function of the Judicature Acts in merging legal and equitable jurisdictions discussed above. In Meagher, Gummow, \& Lehane, supra note 146 at xi, the authors commented that Lord Diplock's statement "represents the low water-mark of modern English jurisprudence." See also note 158, infra.

It could be argued that if certainty was a primary concern of trust law, it would divide trust law into two categories: trusts arising out of intention and trusts arising by operation of law, although as suggested, supra at note 32, all trusts could be said to arise by operation of law for the reasons stated therein.

See S. Smith, "The Stages of Equity" (1933) II Can. Bat Rev. 308 at 310:

A legal principle, in whatever period, aims at establishing a generalization for an indelinite variety of cases. Uniformity and universality must characterize it and these are essential qualities in it. Aristotle, in calling attention to this fact, stated that legal rules are necessarily general while the circumstances of every case are particular, and it is beyond the power of human insight to lay down in advance a rule which will fit all future variations and complications of practice. He concluded that law must be supplemented by equity, there must be a power of adaption and flexible treatment sometimes resulting in decisions which will be even at variance with formally recognized law and yet will tum out to be intrinsically just. 
The desire to combine common law and equitable doctrines is said to be the mark of an "equity pragmatist." 154 According to Smith, the equity pragmatist is one who does not view the common law and Equity as watertight compartments, but as parts of the "tapestry of law," with the result that there must be a principled reason for any deviation between positions at common law and Equity. This person is contrasted with the "equity purist," whom Smith characterizes as one who does not believe that Equity should ever be infused with common law notions. ${ }^{155}$ However, not all commentators who advocate the retention of the theoretical and functional effects of Equity are as absolutist as Smith's "equity purist." Some are more like the reverse image of Smith's "equity pragmatist," in that they are not necessarily opposed to any intrusion by the common law into equitable jurisdiction, but require a principled reason for the infusion of common law notions into Equity's rightful domain.

Recent judicial attempts to combine the precision of law with the flexibility of Equity has only caused greater concem about the misunderstanding of equitable principles. Often, these attempts are based on caricatures of common law and equitable doctrines. Some may be seen to be rooted in convenience, the desire to achieve a particular result, or in vague notions of common sense. ${ }^{136}$ Courts should exercise considerable caution when attempting to combine common law and equitable doctrines rather than attempt to steer a "middle course" between extreme characterizations. Such an apparent compromise, as seen in the Supreme Court of Canada's decision in Peel v. A.G. (Ontario), ${ }^{157}$ has quite different results than lacing Equity with common law principles only in situations where it is both necessary and doctrinally sound. While there has been some degree of fusion of substantive common law and equitable doctrines in many areas of law, it is incorrect to say that that fusion is "real and total," as the Ontario Court of Appeal suggested in LeMesurier v. Andrus. ${ }^{158}$

The raison d'etre of the constructive trust is its function as a corrective device, whether in jurisdictions that view constructive trusts by category, as remedies for unjust enrichment, as being based in good conscience, or any other model. It is imposed by

See L.D. Smith, "Book Revicw - P.M. McDermott, Equitable Damages; M. Cope, ed., Equity: Issues and Trends; J. Glover, Commercial Equity: Fiduciary Relationships" (1996) 75 Can. Bar Rev. 388 at 388-89 (hereinafter Smith, "Book Review"). Jbid. at 389.

15. The latter is seen, for example, in McLochlin J.'s judgment in Canson, supra note 143 at 163 , where she speaks of a "common sense view of causation" in the process of applying common law principles of causation to a breach of fiduciary duty, which historically has looked to a "but for" test of causation. Smith, "Book Review," supra note 154 at 389 describes Canson as "the best example of equity pragmatism in recent Canadian law."

The courts' concern to strike an appropriate balance between predictability in the law and justice in the individual case has led them ... to choose a middle course between the extremes of inflexible rules and case by case "palm tree" justice. The middle course consists in adhering to legal principles, but recognizing that those principles must be sufficiently nexible to permil recovery where justice so requires having regard to the reasonable expectations of the parties in all the circumstances of the case as well as to public policy. 
a court's equitable jurisdiction to correct injustice by having the wrongful holder of property hold that property on constructive trust for the rightful owner. Consequently, rather than being described as institutional or remedial, the constructive trust is better understood as an equitable rectification of a situation gone wrong. It prescribes accountability on the part of certain individuals and confers personal ${ }^{159}$ or proprietary rights on others, in appropriate circumstances, where the dictates of justice require it. 160

By removing the notion that constructive trusts exist only as remedies for unjust enrichment, Soulos removes a major impediment to achieving a greater understanding of the constructive trust and its various uses. It remains to be seen whether Soulos' clarification of the different circumstances in which a constructive trust may be awarded will create confusion as to which form of constructive trust is being used in a particular scenario. ${ }^{161}$ This ought not be a significant concern. By advocating the existence of good conscience-based constructive trusts, the Soulos judgment should be able to push the distracting notions of "substantive," "institutional," and "remedial" constructive trusts into obscurity through its more appropriate, and relevant, focus on what the constructive trust is designed to accomplish, rather than how it has been categorized.

The Soulos judgment also makes apparent the need for Canadian courts to give a more expansive interpretation to the juridical understanding of enrichment as it relates to constructive trusts. That does not mean that constructive trusts ought to be used on an unprincipled basis. A constructive trust should be used only in situations where monetary damages are deemed inadequate ${ }^{162}$ and where third parties, such as creditors, are not unfairly or improperly prejudiced by the awarding of the constructive trust. Any determination of what constitutes a lack of faimess or what is improperly prejudicial is fact and situation-specific and can only be properly determined on a caseby-case basis.

See Ford \& Lee, supra note 32 at 22020 , where the authors distinguish between constnuctive trusts involving a personal obligation to pay money - such as for the disgorgement of profits made by a fiduciary in breach of duty or a payment of compensation for losses - and those involving a proprietary rights, where a person is deemed to hold property on constructive trust for another. See also ibid. at 22000.

16. This concem has led some commentators to argue that the various forms of constructive trusts ought to sufficiently distinguished to avoid the wrongful use of precedent pertaining to one form from being used vis-a-vis another. Note, in particular, Waters, "The Constructive Trust in Evolution," supra note 35 at 372 , where he suggests describing a constructive trust that provides a remedy in rem as a "Humpty Dumpty order" so that it will not be confused with other constructive trusts. See also Smith, supra note 52 at 549 , who suggests describing a constructive trust that grants proprietary relief as a "mandatory injunction to transfer particular assets." As he contends, an injunction, like the constructive trust, is discretionary in nature and is not to be applied if a monetary order is adequate, but avoids the potential for confusion with non-proprictary constructive Irusts.

The fact that constructive trusts are properly used as remedies for breaches of fiduciary obligation and are to be implemented only where monetary compensation is inadequate vindicates the finding in Soulos that a breach of fiduciary obligation may give rise to a proprietary, as opposed to a personal claim. 
In light of the re-examination of Lord Denning M.R.'s "constructive trust of a new model" above, it may be said that it and McLachlin J.'s "good conscience" constructive trust are based upon a common proposition. In creating the new-model constructive trust, Lord Denning M.R. did not advocate the imposition of constructive trusts without reference to established equitable principles. His notion of constructive trusts was clearly premised upon "a liberal process, founded on large principles of equity." 163 As discussed earlier, general equitable maxims provide principled guidelines for more specific equitable doctrines, such as constructive trusts, while establishing the parameters of equitable jurisdiction. Regarded in this light, it would seem that many critics of the new-model constructive trust would have no difficulty accepting it.

For instance, in his judgment in Muschinski v. Dodds, Deane J. boisterously insisted that there was no place in Australian law for the new-model constructive trust. As he stated:

[T]here is no place in the law of this country for the notion of "a constructive trust of a new model" which, "[b]y whatever name it is described ... is ... imposed by law whenever justice and good conscience" (in the sense of "fairness" or what "was fair) "require it": per l.ord Denning M.R. ...Under the law of this country ... proprietary rights fall to be governed by principles of law and not by some mix of judicial discretion ... subjective views about which party "ought to win" ... and "the formless void of individual moral opinion"...

In spite of his professed opposition to the new-model constructive trust, Deane J. said later in his judgment that "there is no reason to deny the availability of the constructive trust in any case where some principle of the law of equity calls for the imposition upon the legal owner of property, regardless of actual or presumed agreement or intention, of the obligation to hold or apply the property for the benefit of another." 165 How that statement differs from Lord Denning M.R.'s constructive trust based on "a liberal process, founded on large principles of equity" is unclear. Indeed, as Deane J. himself acknowledged in Muschinski, his opposition to the new-model constructive trust "is not to say that general notions of faimess and justice have become irrelevant to the content and application of equity." 106 As discussed earlier, the new-model constructive trust fulfils Deane J.'s requirement that constructive trusts be premised upon "established equitable principles or by the legitimate processes of legal reasoning, by analogy, induction and deduction, from the starting point of a proper understanding of the conceptual foundation of such principles." 167

In addition to focussing attention on the purpose of the constructive trust, the good conscience-based constructive trust is easily reconciled with existing constructive trust situations. For example, the constructive trust as a remedy for unjust enrichment developed in Pettkus v. Becker may be seen to prevent those who are unjustly enriched

Hussey v. Palmer, supra note 17 at 1289-90. Muschinski, supra note 35 at 65.

Ibid. at 66.

lbid.

Ibid. at 65 . 
from retaining property that, in good conscience, they ought not retain. The good conscience standard is also more consistent with other forms of constructive trust that cannot be explained by the principle of unjust enrichment, such as fully secret trusts, mutual wills, and imperfectly constituted trusts. What was largely unresolved in Soulos, though, is how the good conscience constructive trust will affect third parties, such as creditors.

\section{The Effect of Constructive trusts on Third Parties}

Often, a court's sole consideration as to whether to impose a constructive trust in a particular situation is its effect on the parties to the litigation. In many situations, however, third parties are equally affected by a court's decision to impose, or not impose, a constructive trust. In this section, the interests of creditors will be discussed to indicate what type of consideration ought to be given by courts to the interests of third parties in determining whether to award a constructive trust.

When a constructive trust is imposed over specific property, that property is determined to belong to a person or entity other than the one in possession of it. Once a declaration of constructive trust is made, the person in possession is required to hold the property for the benefit of another and the property is segregated from the assets of the former. Consequently, if the person in possession was bankrupt, that person's creditors would not be entitled to attach to property in the former's possession that is subject to a constructive trust.

Upon first glance, there does not appear to be any problem with this situation. Creditors are only entitled to attach to property properly belonging to those indebted to them. If property in the possession of a debtor is subject to a constructive trust, then it no longer belongs to the debtor and the debtor's creditors are not entitled to it. What is important here is the timing of the constructive trust, specifically whether the constructive trust, once declared over specific property, takes effect from the time of the declaration or if it has a retrospective effect. While this topic has generated some debate, ${ }^{168}$ it is moot with respect to the court's ability to award constructive trusts. ${ }^{169}$ Since the awarding of a constructive trust is discretionary, it may properly

See, for example, Bedard v. Schell (1987), 26 E.T.R. 225 (Sask. Q.B.); E.L. Sherwin, "Constructive Trusts in Bankruptcy" (1989) 2 U. Illinois L. Rev. 297; and R.M. Goode, "Property and Unjust Enrichment" in A. Burrows, ed., Essay on the Law of Restitution (Oxford: Clarendon Press, 1991).

There are, however, important implications on the parties to the litigation, as well as on third parties with related interests, where constructive trusts have retrospective application. Note, for example, the situations posited by Waters in "The Constructive Trust in Evolution," supra note 35 at 361 :

What about the position of a third person who innocently and for value acquires a lien on the property from the title holder between the date of unjust enrichment taking place and the date of trial? What should be said as to judgment creditors of the enriched party; such creditors attach the disputed asset, only to find later at the trial when restitution is claimed that the defendant is an unjustly enriched party who was not entitled to the asset at the time of the attachment? Problems arise even with the enriched party himself. He is vested with the disputed capital. Does he have an obligation to pay taxes on current income arising in 
be modified to fit the specific needs of individual situations. It is, therefore, incorrect to say either that constructive trusts always take effect from the time of declaration or that they are necessarily retrospective in their application. Courts, in exercising their discretion over the imposition of constructive trusts, must account for the circumstances in which the constructive trust would exist, taking care to ensure that the interests of third parties are not unfairly subordinated to those of the parties to the litigation. In paying particular attention to these circumstances, the courts may order that a constructive trust take effect from the time of declaration, when the property in question came into the possession of the defendant, or at any time in between. ${ }^{170}$

Another issue that has generated discussion is whether a plaintiff, who would otherwise be an unsecured creditor, ought to be able to take priority over other creditors through the imposition of a constructive trust. Put another way, should the constructive trust be regarded as an enforcement of pre-existing property rights or as a means of establishing priorities between the claimant and other creditors? ${ }^{17}$ Unsecured creditors are certainly at risk where constructive trusts are imposed upon their debtors. Yet, since La Forest $\mathrm{J}$. explained in $L A C$ Minerals that a constructive trust may recognize existing rights of property or create new rights, ${ }^{172}$ even secured creditors' interests may not be immune from the effects of constructive trusts. ${ }^{173}$ Because a constructive trust may be awarded long after a declaration of bankruptcy, it may be quite difficult for creditors to properly protect their interests vis-à-vis the assets of another person who is found to be a constructive trustee.

In some situations, plaintiffs have sought judicial declarations of constructive trust in attempts to leapfrog over other creditors. Such a situation occurred in Waselenko v. Touche Ross Lid. ${ }^{174}$ In that case, the Waselenkos had contracted with Swertz Brothers Construction Ltd. (Swertz) to build them a pre-fabricated house for $\$ 65,000$. Swertz was given $\$ 500$ as a down payment and was to receive $\$ 32,500$ on the completion of blueprints, $\$ 30,000$ when the house was delivered, and the final $\$ 2,000$ when the Waselenkos approved the construction. Under the terms of the contract, the house

the tax year from that capital, but, as things turn out, between the date of unjust enrichment and the date of trial?

170 Note Muschinski v. Dodds, supra note 35.

171 In Sherwin, supra note 168 at 306, the author argues that a plaintiff seeking a constructive trust ought to gain priority over other creditors only where the creditors would be unjustly enriched by sharing in property claimed by the plaintiff. She contends, at 312 , that the constructive trust, as it is currently used, does not enforce pre-existing property rights, but prioritizes the claimant's claim to assets over those of the defendant's other creditors. Meanwhile Goode maintains that if a plaintiff has no pre-existing restitutionary interest, the plaintiff ought to accept the same risk of the defendant's insolvency as the defendant's other creditors: see Goode, supra note 168 at 240.

17. See supra note 86 .

in However, as Goode has noted, supra note 168 , in such circumstances, it is possible for a court to declare that a constructive trust is to be effective without prejudice to the prior rights of secured creditors. Alternatively, as in Messchinski v. Dodds, supra note 35, a constructive trust may simply be ordered to operalt pro munc (as of the date of declaration), not pro tunc (having retrospective application).

$114 \quad$ [1983] 2 W.W.R. 352 (Sask. Q.B.), aff [1985] 3 W.W.R. 38 (Sask. C.A.). Note also Taypotat v. Surgeson, [1985] 3 W.W.R. 18 (Sask. C.A.). 
belonged to Swertz until it was completed and delivered to the Waselenkos and the final instalment of the contract was fulfilled. After it had completed the blueprints, but before it could finish building the house, Swertz was put into receivership by the Canadian Imperial Bank of Commerce (CIBC). To that point, Swertz had been paid $\$ 33,000$ and the house was only partially built. The receiver, Touche Ross, decided not to complete the house because the estimated cost of completion was greater than the amount outstanding under the agreement with the Waselenkos. CIBC laid claim to the house as security for a demand debenture that predated the Waselenko contract. The Waselenkos sought a court order that all property interests in the house that they did not possess were held on constructive trust for them by Touche Ross.

The Waselenkos' claim was strategic. If they were successful in having the partiallybuilt house declared to be subject to a constructive trust, it would be segregated from Swertz's property and pass to the Waselenkos. If they were unsuccessful, the house would be Swertz's property and the Waselenkos, as unsecured creditors, would rank pari passu with Swertz's other general creditors and behind CIBC. In finding in favour of the Waselenkos, Geatros J. found that Touche Ross held the partially-built house on constructive trust for CIBC, subject to the prior interest of the Waselenkos in the amount of $\$ 33,000$ plus a percentage of any increased value of the house. ${ }^{175}$

While the Waselenko decision may be objectionable in light of the test established in Petkus, ${ }^{176}$ since there was an enrichment, deprivation, and a juristic reason for the enrichment (the terms of the contract), it must now be reappraised in light of Soulos. What now needs to be asked is whether, in good conscience, Touche Ross, acting on behalf of Swertz, ought to have been entitled to retain the money paid by the Waselenkos in addition to keeping title to the partially-constructed house. ${ }^{177}$ The existence of a contract will not preclude the awarding of a constructive trust. In some situations, a contract may provide a juristic basis for a defendant's enrichment, but that point may become moot if it is found that the defendant may not, in good conscience, be entitled to retain the fruits of the contract.

Another question which has sometimes been raised when considering cases such as Waselenko is whether persons who would otherwise be unsecured creditors, but who are elevated to a position of priority vis-à-vis other creditors because of a finding of constructive trust, ought to be given priority or whether they ought to be understood

13s The Waselenko case resulted in the Waselenkos gaining priority over all of Swerz's creditors, both secured and unsecured. By having a constructive trust prevent a bankrupt's creditors from attaching to assets subject to the constructive trust, the claimant gains priority over even secured creditors unless the court makes the constructive trust subject to the interests of the secured creditors. See the discussion in supra note 173.

17t. It may also be objectionable as an unfounded alteration of creditor priorities. As Waters stated in "New Directions in The Employment of Equitable Doctrines: The Canadian Experience" in T.G. Youdan, ed., Equity, Fiduciaries and Trusts (Toronto: Carswell, 1989) at 429: "there is something profoundly disturbing about a situation where contractual non-performance is caused by the nonperformer's bankruptcy, where no wrong-doing of the bankrupt occurred nor did the payor act in mistake, and yet the payor goes ahead of the bankrupt's general creditors." With the result that CIBC would be entilled to both as security for the demand debenture. 
to have undertaken the same risks as other creditors and ranked pari passu with the latter. Paciocco, for one, holds that for a proprietary remedy, such as a constructive trust, to be awarded, there must not only be a causal connection or nexus between the plaintiff and the property, but also the plaintiff must not be understood to have accepted the risk of the defendant's insolvency ${ }^{178}$ The difficulty with the latter proposition, as Paciocco acknowledges, is that not all general creditors have accepted the risk of a defendant's insolvency, while some potential constructive trust claimants have accepted that risk. ${ }^{179}$

In conjunction with the acceptance of risk argument, it could be argued that if a creditor wants protection in the event of a debtor's bankruptcy, the creditor may seek security from the debtor in accordance with the appropriate legal regime for creditors' protection. Yet, as discussed earlier, the fact that a constructive trust may create new rights of property could have the effect of making even secured creditors vulnerable to a judicial declaration of constructive trust. ${ }^{180}$ It is sometimes argued that where a person advances money to another under a contract for services and those services are not performed, such as in Waselenko, the former is entitled to gain priority over general creditors of the latter because the money was advanced under a quid pro quo that went unfulfilled. It is not always easy to see how this situation may be differentiated from that of the supplier who provides materials to a company on credit, fails to register a security interest in the company's assets, and does not receive payment before the company becomes bankrupt. ${ }^{181}$ Is this not also an unfulfilled quid pro quo? Ought the supplier thus be entitled to a declaration of constructive trust rather than be classified as an unsecured creditor? From this juxtaposition, it is clear that simply because a party is in possession of assets, but has not paid for them, that party is not automatically to be declared a constructive trustee, nor, equally, is the provider of those assets entitled to become the beneficiary of a constructive trust.

Supra note 47 at 350 . See also the commentary on this point in Sherwin, supra note 168 at 335-37, 350-60; J. Glover, "Bankruptcy and Constructive Trusts" (1991) 19 A.B.I.R. 89 at 121-22. Note also Goode, supra note 168 at 242 , who says that while a general creditor may have voluntarily extended credit to a defendant - and thus may be deemed to have accepted the risk of the defendant's insolvency - that fact is more than offset by the fact that the creditors were given value in return (e.g. a contracutal promise to pay for goods provided) while, in a purely remedial constructive trust situation (where the plaintiff has no proprietary base for a claim), the plaintiff has not provided any value.

Paciocco, supra note 47 at 325 . Paciocco also acknowledges that the acceptance of risk argument is harsh vis-â-vis certain individuals, such as small trade creditors, owing to the expense associated with conducting searches or facilitating security arrangements. See supra notes $172-73$.

I*I As Paciocco cxplains, supra note 47 ut 350 : "[w] beneficiary from the general creditors of the defendant is that the general creditors can be taken to have accepted the risk of the defendant's insolvency in their dealings with him, while the constructive trust beneficiary cannot." If general creditors are deemed to have accepted the risk of the defendant's insolvency, should they not also be expected to have taken measures to protect themselves against such an occurrence by seeking security against the defendant's assets? Accordingly, should creditors' failure to protect their own interests when they are to be deemed to have accepted the risk of the defendant's insolvency mitigate against their entitlement to judicial remedy where they fail to take such precautions? 
In general, a constructive trust ought to give priorities over other creditors only where there is a legitimate reason for subordinating creditors' rights to those of the plaintiff seeking the constructive trust. ${ }^{182}$ If the plaintiff's claim is not demonstrably superior to those of the other creditors, then logic and reason dictate that there is no reason to rank the plaintiffs claim ahead of the others'. One situation where a plaintiff's claim would be demonstrably superior to those of ordinary creditors is where monetary damages are inadequate, such as where a unique item has wrongfully come into the possession of the bankrupt. Where monetary damages are adequate, the ordinary scheme of creditor priorities should be followed - unless it can be demonstrated that extraordinary circumstances exist which warrant a disruption of normal creditor priorities, such as in the Chase Manhattan case, discussed infra.

A more complicated situation arises where there is no clear-cut entitlement of either the plaintiff or defendant to property that is subject to a claim of constructive trust. An example of this may be seen where a person in a fiduciary position takes a bribe from a third party to act in the third party's interests and contrary to the beneficiary's best interests. If a director of a corporation takes a bribe from a third party supplier in exchange for ensuring that the corporation purchases the supplier's goods at a premium price and the director subsequently becomes bankrupt, who is entitled to the bribe money, the corporation or the director's creditors? In this situation, the corporation ought to be entitled to the money even though the money did not come from it and never belonged to it. ${ }^{183}$ As Maudsley has explained, "[t]he right of the creditors is to participate in the debtor's estate. If the debtor obtains property wrongly, that is no reason to enrich the creditors with this windfall. They are entitled only to that which the debtor obtained properly." ${ }^{184}$

Some commentators have disagreed with this reasoning. For instance, Paciocco has suggested that where a fiduciary earns profits through a breach of fiduciary obligation and is forced to hold those profits on constructive trust for the beneficiary of the fiduciary relationship, the beneficiary is wrongfully in receipt of a windfall where those profits exceed the quantum of the beneficiary's deprivation. ${ }^{185}$ While he contends that relief ought to be available to the beneficiary to the extent of the beneficiary's deprivation, if the fiduciary's enrichment is greater, the beneficiary is no more entitled to the excess than the corrupted fiduciary. Where the fiduciary is bankrupt, Paciocco contends that the fiduciary's creditors ought to be entitled to the excess. Since he

As Goode, supra note 168 at 244 , correctly argues, a debtor's bankruptcy or impending insolvency ought not constitute a legitimate reason for giving a plaintiff priority over the debtor's other creditors. In fact, Goode argues that a debtor's bankruptcy or impending insolvency ought to provide protection for the creditors against those seeking a proprietary remedy via a constructive trust.

17s Unless, of coursc, the director can demonstrate the receipt of the corporation's fully-informed consent to the transaction with the third party or where the receipt of the "bribe" may be demonstraled to be an accepted industry practice or custom. On this latter point, see Cope, "Ownership, Obligation, Bribes," supra note 86 at 103.

im Maudsley, "Proprietary Remedies," supra note 35 at 242.

iss Supra note 47 at 349. See also R.M. Goode, "Ownership and Obligations in Commercial Transactions" (1987) 103 L.Q. Rev. 433. 
maintains that the beneficiary's only claim to the excess is that the fiduciary should not be able to retain it, he suggests that giving the excess to the creditors still keeps it away from the fiduciary, but avoids generating an unwarranted windfall. ${ }^{186}$

While Paciocco is correct in identifying one rationale for the beneficiary's claim to the entirety of the fiduciary's ill-gotten gain, ${ }^{187}$ he fails to appreciate that the fiduciary does obtain a benefit where the excess of profits over deprivation goes to the fiduciary's creditors. In such a situation, the fiduciary's indebtedness to the creditors is reduced, thus conferring a real and tangible benefit to the fiduciary. This scenario is similar to that in Citadel General Assurance Co. v. Lloyds Bank Canada, ${ }^{188}$ where the Supreme Court of Canada held that the bank's set-off of insurance premiums belonging to Citadel against the indebtedness of one of the bank's clients conferred a benefit upon the bank which fulfilled the requirement of receipt of property necessary to satisfy the test for knowing receipt of property in breach of trust. ${ }^{189}$ As Cope has explained, "[p]rima facie creditors are not entitled to profit from the net gain which is the result of a breach of duty."190 The principles applying to the excess of a fiduciary's wrongful gain over the beneficiary's loss apply equally to the increase in value of an asset in circumstances where a bribe comes in the form of property that appreciates in value between the time it is given and the awarding of a constructive trust. In that situation, the successful claimant, not the fiduciary's creditors, is entitled to any increase in the value of the property. ${ }^{191}$

In conclusion, it may be said that while the constructive trust has the potential to do injustice to established schemes of creditor priorities, it does not necessarily follow that the imposition of constructive trusts must disrupt such schemes or create injustice. The discretionary nature of the constructive trust enables courts to tailor their application of those trusts where necessary or appropriate. Furthermore, if courts are cautious in their application of constructive trusts and use them only where they are appropriate and do not unfairly prejudice the legitimate interests of third parties, then the potential dangers that exist may be avoided.

In McLachlin J.'s majority judgment in Soulos, she stressed the need to consider the effects of constructive trusts on third parties, such as creditors, before imposing them

Supra note 47 at 350 . See also Sherwin, supra note 168 at 339.

A more legitimate rationale for giving the excess to the beneficiary in this type of situation is that the bribe constitutes the means by which the fiduciary's loyalty was transferred from the beneficiary to a third party and, as such, must be disgorged. In addition, under established fiduciary principles, fiduciaries are not entitled to retain any benefit from wrongdoing as a means of deterring fiduciaries from acting contrary to their obligations to their beneficiaries. See the discussion in Cope, "Ownership. Obligation, Bribes," supra note 86 at 124-25. For a contrary view, see Sherwin, supra note 168 at $346-47$.

Supra note 10.

See the requirements for liability for knowing receipt, which is discussed, supra note 11.

Cope, "Ownership, Obligation, Bribes," supra note 86 at 97. In contemplating net gain, Cope is allowing for the possible reimbursement of cost of acquisition and allowances for any increase in value to the party in breach of duty coming about as a direct result of improvements or efforts of the party in breach. See also Boardman v. Phipps, [1967] 2 A.C. 46 (H.L.).

See A-G. Hong Kong v. Reid, supra note 86; Cope, ibid. at 116-17. 
on a particular situation. While she did not discuss some of the potential detriments to creditors by the imposition of a constructive tnust, she did recognize that third parties may be seriously affected by the imposition of constructive trusts. Her statement that constructive trusts should not be imposed without first considering the creation of injustices done to third parties ought to be regarded as a practice directive towards other judges faced with decisions as to whether to award constructive trusts in particular circumstances.

\section{Conclusion}

While this article has advocated the extension of the constructive trust based on the principle of good conscience, some additional convincing may be required. It is legitimate to ask why a vague and relatively unarticulated good conscience-based constructive trust is preferable to the traditional English "substantive" constructive trust or the constructive trust-as-remedy for unjust enrichment. While the degree of discretion given to judges using the good conscience model may create discomfort for some, it provides a far more clearly defined methodology for ascertaining whether a constructive trust ought to be imposed in a given situation. As has already been discussed, the unjust enrichment-driven constructive trust cannot account for situations of fully secret trusts, mutual wills, or other scenarios in which constructive trusts have been used as a device to prevent fraud. Unjust enrichment is also incapable of explaining the use of a constructive trust to perfect an incomplete gift in a case such as Re Rose. ${ }^{192}$ Therefore, it is possible to conclude that unjust enrichment is unsuitable as a basis for understanding all situations in which constructive trusts have, or may, be used.

A rejoinder to the suggestion that unjust enrichment is an unsuitable doctrinal basis for understanding the situations in which constructive trusts have been implemented is that the imposition of constructive trusts in situations other than unjust enrichment are simply incorrect usages. To answer this rebuttal, it is necessary to look at one of the most important benefits to using the good conscience model constructive trust - the elimination of legal fictions.

Doctrinal certainty cannot be achieved through the invention of artificial criteria in order to fit within established methodologies. It is important to maintain some measure of certainty between legal institutions. Indeed, the coherent development of law depends upon the ability to differentiate between various legal doctrines. Where legal fictions result in the improper or incorrect application of particular principles to achieve a certain result, confusion reigns. Such a situation may be seen in the Chase Manhattan case. $^{193}$

In Chase Manhattan, the plaintiff, Chase Manhattan Bank, had transferred two million dollars into the defendant, Israel-British Bank's account. That same day, a clerical error by Chase Manhattan caused it to transfer a second two million dollars into the defendant's account. The defendant was put into receivership shortly thereafter.

(3) Supra note 36. 
Chase Manhattan was successful in its action for the return of the second two million dollars, but only after the court concocted a fiduciary relationship between the two banks. As Goulding J. explained it, to allow Chase Manhattan to recover the funds, it was necessary to find that the parties were in a fiduciary relationship before the court could allow Chase Manhattan to trace funds in equity. ${ }^{194}$ Consequently, he found that a fiduciary relationship existed between the parties so that a constructive trust could be imposed on the mistakenly-transferred funds. ${ }^{195}$

In the Chase Manhattan case, the finding of a fiduciary relationship to enable the court to impose a constructive trust may be seen to have created doctrinal uncertainty in fiduciary law because the circumstances did not warrant such a finding. While it is important to maintain the separation of established doctrine, the difficulty comes in doing so while preserving the requisite flexibility required to respond to the particular needs of unique situations. ${ }^{196}$ The constructive trust based on good conscience eliminates the need to create legal fictions in order to impose constructive trusts. Rather than having to create a fiduciary relationship where there was no basis for one, as in the Chase Manhatlan scenario, a good conscience-based constructive trust would have enabled the judge to simply inquire whether the recipient of the mistakenly-forwarded funds ought, in good conscience, be able to retain them. In answering this question, it would have to be asked how and why the recipient acquired the funds. The fact that a mistake occurred and that there was no positive reason in law why the defendant bank ought to be able to keep the funds would constitute a sufficient basis upon which to support the imposition of a constructive trust in such a situation.

Why have judges found the need to create such fictions? The answer may be seen in the artificial and overly-restrictive constraints that have sometimes been imposed on constructive trusts. These constraints have resulted in the judicial manufacture of falsehoods, as in Chase Manhattan. In addition to the restrictive environment surrounding the application of constructive trusts, the concepts of enrichment and deprivation have often been interpreted rather narrowly by the courts. Justice Sopinka's judgment in Soulos is indicative of this limited approach.

Viewed in their proper contexts, constructive trusts based on notions of good conscience, fairness, and justice are no more formless than other equitable doctrines, such as fiduciary relationships. Of course, there is significant concern among judicial and academic commentators over the lack of definition or guidelines for fiduciary relationships. Regarding equitable maxims as principled guidelines for the application of malleable equitable doctrines such as constructive trusts and fiduciary relationships ought to lessen concern about the latter's perceived formlessness. Meanwhile, it must

Based on his reading of the precedent in Re Diplock, [1948] Ch. 465 (C.A.), affd (sub nom. Minister of Health v. Simpson), [1951] A.C. 251 (H.L.).

For a similar situation, in which a court created a fiduciary relationship to allow for the following of money, see Goodbody v. Bank of Monireal (1974), 47 D.L.R. (3d) 335 (Ont. H.C.).

As McLachlin J. explained in "The Place of Equity," supra note 71 at 40: "The law should be predictable so that people can arrange their affairs in an orderly fashion; uncertainty brings its own injustices. But at the same time, the law must also be able to accommodate new and aberrant situations without producing injustice." 
be acknowledged that discretion is an essential element of judicial decision making. As C.K. Allen has explained, "an element of discretionary justice is and always has been essential to the efficient interpretation and application of law." 197 This is particularly true of equitable doctrines, which tend to be more flexible and wide-ranging in their application. Of course, that is the result of the historical function and jurisdiction of Equity, discussed earlier.

As a creature of Equity, the constructive trust ought to be able to maintain the inherent flexibility that is one of Equity's great attributes. At the same time, it ought not be imposed on an unprincipled basis. Furthermore, it should not be used simply to achieve a particular result if the effect would be to perpetrate an injustice on the defendant or on third parties, such as creditors, or where it would give an unwarranted benefit to the plaintiff. Because of its power, the constructive trust has the ability to rectify injustice in a vast array of situations. Yet, if it is used improperly or without reference to principle, it can equally create injustice. For this reason, the constructive trust should be used wisely and cautiously. As Maudsley has commented:

The constructive trust is an instrument created by the law to do justice. It needs to be flexible, so that it can be used to meet new situations as they arise. But it needs to have some shape. Lawyers have to advise. Litigants need to know. ... [I] the courts are to wield such a powerful and secret weapon, let it be confined to cases where its use is essential to achieve justice. ${ }^{\text {in }}$

While the constructive trust ought to be confined to situations where it is appropriately used and does not create injustice, its wise and cautious use should not be understood as a licence to reign it in and deprive it of its equitable nature.

Through its decision in Soulos, the Supreme Court of Canada has sanctioned the good conscience constructive trust as the standard for understanding constructive trusts in Canadian law. With this decision, it may now be possible to say that Canada has taken a significant step towards what Lord Denning described in Landmarks in the Law as "the new equity." This new Equity, as he explained, "is fair and just and flexible, but not as variable as the 'Chancellor's foot."'199 In embracing this new Equity, the Supreme Court is returning to the historic role of Equity as a means of mitigating the "rigour, hardness, and edge of the law." One can only hope that the rationale that exists at the foundation of the "good conscience" constructive trust is granted the opportunity to flourish. Perhaps then it may be able to transcend the constructive trust and have equally significant effects in other appropriate situations.

197 C.K. Allen, Law in the Making, 7th ed. (Oxford: Clarendon Press, 1964) at 425.

19n Maudsley, "Constructive Trusts," supra note 3 at 137.

199 Denning, supra note 141 at 86. As examples of this "new equity," Lord Denning cited the doctrines of promissory estoppel, proprietary estoppel, constructive trusts, licences of land, and the granting of injunctions. 